\title{
FINANCIAL STABILITY OF THE BANKING SECTOR AND SECURITY OF THE BACKBONE BANK ACTIVITES IN THE EXCHANGE MARKET IN THE CONTEXT OF NATIONAL ABILITY TO IMPLEMENT THE EUROPEAN GREEN DEAL
}

\section{Serhii Petrukha ${ }^{1}$ \\ Mykola Korolenko}

DOI: https://doi.org/10.30525/978-9934-26-021-6-19

Abstract. The article consistently grounds that a collision of the existing eco-nomic model with financial-economic, social-and-food and institutional challenges generated by the COVID-19 pandemic jeopardizes achieving the nationally priori-tized Sustainable Development Goals by 2030, in particular, associated with the anti-crisis reaction to an imbalance of nature management, ecology, sustainability of formation of agricultural valuedadded chains as well as enroots a lag of the national regulating financialand-economic system behind the New Green Deal chosen on a planetary scale and on the European continent - the European Green Deal. To neutralize this crisis gene, the article grounds the need not only to develop respective concepts, strategies, programs, approaches to the economic stimulation and budgetary financing, but also determines crying reality low activity of the banking sector as a financial donor in implementing respective measures for achieving national "green" goals, in restructuring the economy due to high volatility of current processes. This crystallized the subject of research - a role of the banking sector in the formation of the national ability to implement the European Green Deal through the lens of financial sustainability, security of its activities in exchange markets. As first methodological steps, symbiotics is offered, putting together traditional tools of scientific research with a non-orthodox combination of material and computational financial-and-economic experiments allowing to conduct

${ }^{1}$ Candidate of Economic Sciences,

Associate Professor of the Department of Financial and Economic Security,

"KROK" University, Ukraine

${ }^{2}$ Candidate of the Department of Management in Construction, Kyiv National University of Construction and Architecture, Ukraine 
targeted research - the state of the banking sector of the country and security of activities of one of the backbone banks - PrivatBank, in general, and in the exchange market, in particular. It was proved that the lack of synchronicity of the regulation of the European Green Deal, Ukraine's Green Deal and a methodological basis of financial stability, in general, and macro-prudential policy, in particular, has generated information asymmetry in assessing the potential of the banking sector to provide normative regulations in the "greening" of sectors of the national economy. In this context, the Ministry of Energy and Environmental Protection of Ukraine presented, at the beginning of 2020, a draft Concept of "Green" Transition of Ukraine until 2050, which implementation will take place using financial instruments tested within the framework of "warm" loan programs carrying new opportunities for the PrivatBank's participation in the "greening" of the national economy including that by crediting projects of complex thermomodernization of both multi-apartment and individual houses. As a result of implementing the Green Deal, the economy of Ukraine will drastically change, new sectors, new industries will appear within the framework of the traditional rural economy and environmental economy while a link between the economic growth, on the one hand, and resource consumption, environmental contamination, greenhouse gas emissions, on the other hand, will be broken. In this context, in order to maintain own leading positions in the segment of the regulatory providing and financing of modernization of small and medium business in the direction of its "greening", the PrivatBank needs to immediately actualize the provisions of its strategy until 2022, subject to new market segmentation, prioritization of recipients of loans, their channeling, first of all, for the needs of the "green" modern.

\section{Introduction}

At the moment, Ukraine faces not only the challenges traditional to it, such as a need to diversify the economy and reduce in the dependence on the agrarian sector (9\% or UAH 358 B are created by the sector in 2019 [32], but also a decline on the global business activities in connection with the COVID-19 pandemic and a related drop in demand and prices for agricultural deep processing products (the FAO food price index, using which monthly changing in international prices for food goods staples is tracked, was, for the last quarter, 172.2 percentage points that is 4.3 percentage points lower 
than in the second quarter 2020 [27]), which can become long-term. Further, some large world economies including neighbor countries start a large-scale transformation of their economic systems, in general, and agrarian systems, in particular, as a response to global climate and ecological crises. With no timely and proper response to these phenomena, Ukraine risks to increase its economic and technological lagging behind leading world economies and, paradoxically, become an outsider in the global food marker. The way, in which Ukraine will go out of the COVID-19 crisis, will, to a great extent, determine a trajectory of its economic development for the coming years or even decades that is seen in The Economic Stimulus Program to Overcome the Consequences of the COVID-19 Epidemic COVID-19 [32] and The Basics of Strategic Reform of the State Banking Sector [13], offered by the Government.

We will emphasize that, after the beginning of the pandemic, tens of civil society organizations, corporations and even ministers of the leading countries of the world presented their vision of the exit from the COVID-19 crisis. The overwhelming majority of these statements contains a call to stimulate the economy by developing "green" sectors in response to a "green" vector, chosen by the European Union (EU), for political, economic, sectoral, institutional and financial development, closely enough correlating with a need to counter new challenges in the global arena in achieving the UN Sustainable Development Goals b 2030 [50]. It follows that the EU has not only maintained its commitment to the European Green Deal announced before the beginning of the COVID-19 pandemic, but has also continued its implementation, in particular, by a program stimulation, participated by financial-and-credit institutions, of "green" sectors of the economy within the framework of its anti-crisis policy. In order to determine the framework of banks' participation in the anti-crisis policy, implementation of measures of the European Green Deal, as well as form a new coronavirus-resistant system of financing of the transition to a low-carbon future, the European Commission engaged BlackRock Inc., an international investment company (the largest in the world by assets under management - US\$ 7.430 T [37]). Governments of China, Japan, South Korea as well as Joe Biden, the elected President of the USA, publicly promised to determine, in the nearest time, official goals of the transition to carbon neutrality (including a clean energy industry and emissions) by the middle of the century. 
The New Green Deal ideas [46] - stimulation of the economy through invest-ing in infrastructure and creating new jobs with a focus on "green" sectors - are de-veloping in the world beginning from 2007. After the previous severe global crisis of 2008-2009, in the Group of Twenty countries, the "green" sectors of the economy received nearly $16 \%$ of all anti-crisis expenditures [42] and this can be considered an approbation of the concept of the New Green Deal and an empiric prerequisite of the EU transition to the European Green Deal. Ukraine did not use then a chance to diversify the economy, in general, change the priorities in developing the agrarian sector from the production of agricultural raw stuff to the formation of sustainable value-added chains by deepening the processing of agricultural products. Lagging has been seen not only in the political aspect but also in the scientific substantiation of the said need for "green" modernization of the national economy. So, a base scientific institution the Institute of Environmental Economics and Sustainable Development of the National Academy of Sciences of Ukraine - has elaborated sufficient material on sustainable development of the national economy subject to global ecological and climate trends (for example, [12; 34]), but the matters associated with the financial architecture of the said process, in general, a place of financial-and-credit institutions in it, in particular, have remained low-studied, forming an effect of informational asymmetry and institutional uncertainty of the running of "green" reforms, institutionalization of "green" finances, which play out in fresh colors in the context of the modern "ecology - climate - nature management-food - "green finances" construct (for example, considered in [39; 41]), actualizing such kind of research. We will emphasize that, in the regulatory realm, the Government, within the framework of The Basics of Strategic Reforms of the State Banking Sector (to reduce a state share of the banking sector from 60 to $25 \%$, reduce a portion of non-operating assets on balance-sheets of state banks, by 2025) determined an impact of backbone banks on the insti-tutional-and-sectoral reconstruction of the economy of Ukraine, namely, for small and medium business, PJSC CB "PrivatBank" is decided to be a provider of financial resources for their "greening".

Subject to the above facts as well as to existence of a sustainable trend towards forming unfavorable financial-and-economic and foreign-policy conditions, insufficient stability of the functioning and development of the 
public finance management system, it becomes increasingly dangerous to lose the next opportunity of moving away from an agrarian-and-row stuff "curse", that allowed to determine the purpose of this research - studying a level of financial stability of the banking sector and security of the activities of backbone banks in the exchange market within the framework of the existing and prospective (until 2030) national potential for the implementation of the European Green Deal.

To form and scientifically substantiate the Green Deal of Ukraine, it is needed to make first methodological steps within the framework of the methodology, offered by us, putting together traditional research tools with a nonorthodox combination of material (classical) and computational financial-and-economic experiments (initial information on the functioning of the banking sector and exchange market, a qualitative and quantitative observation over the results of activities of one of the backbone banks - PJSC CB "PrivatBank", in general, and in the exchange market, in particular. For the purpose of complexity of this study we offered, within the framework of research presented below, a three-vector combination of research tasks, forming the next logic of structuring the materials:

first vector - diagnosing financial stability of the banking sector interspersed with a place and role of the backbone bank - PJSC CB "PrivatBank";

second vector - studying interinfluence and interconnections of the security of the development of the banking sector and exchange market as a donor financial system for the "greening" of sectors of the national economy;

third vector - taxonomic monitoring of security of the activities of PJSC CB "PrivatBank" in the exchange market within the financial institution and state provi-sion of development and implementation of the framework program for the long-term development of Ukraine until 2050, being in line with key modern development documents - The Paris Climate Agreement [45] and The 2030 Agenda for Sustainable Development [52].

The above proposed three-vector combination will allow to offer a new (novelty) interdisciplinary mix of ecological, climate, sectoral and financial aspects of development of the national economy, supplement respective mono-studies (ecology or state banks) with a place and role of the "backbone bank - climatic neutrality" combination bringing the banking sector in the "greening" of the economy of Ukraine to the forefront. 


\section{Monitoring of financial stability of the banking sector within the framework of a new paradigm of the "greening" of the national financial-and-economic model of development}

The banking sector of Ukraine has developed very unevenly in recent years. Periods of significant growth were intertwined with crisis periods. At the same time, according to [11;53], the total assets (liabilities) of the banking sector as of January 1, 2018 amounted to UAH 1,278 B (USD 160 B), which was 17.5 times less than the assets of the German Deutschmark Bank (USD 2802.7 B), which held 1st place in the ranking of the largest banks by assets in the Top Banks in the World 2018, and 8.3 times less than those of the Italian UniCredit (USD 1331.9 B), which held 24th place. It should be noted that in the periods 2014 and 2018, the increase in assets of most banks was mainly due to the revaluation of their hryvnia equivalent in foreign currency after the devaluation of hryvnia. This led to an increase in their deductions to reserves for foreign currency loans, which triggered the need to replenish their capital. Thus, JSC "Ukreximbank" sent for this purpose billion UAH, JSC "Oschadbank" - UAH 12.2 B, JSC "Prominvestbank" UAH $4.3 \mathrm{~B}[11 ; 14 ; 19 ; 53]$. For a long time, there has been a positive trend in most of the key indicators that characterize the role of the banking sector in the economic dynamics of the national economy (Table 1.1).

Table 1.1

\section{Dynamics of key financial security indicators of the banking sector}

\begin{tabular}{|l|c|c|c|c|c|}
\hline \multirow{2}{*}{ Indicator } & \multicolumn{5}{|c|}{ Researched period } \\
\cline { 2 - 6 } & $\mathbf{2 0 1 4}$ & $\mathbf{2 0 1 5}$ & $\mathbf{2 0 1 6}$ & $\mathbf{2 0 1 7}$ & $\mathbf{2 0 1 8}$ \\
\hline Total assets & 87.0 & 92.0 & 80.0 & 96.8 & 113.0 \\
\hline Loans granted & 69.8 & 62.7 & 57.9 & 62.7 & 74.8 \\
\hline Equity capital & 12.7 & 11.8 & 12.0 & 13.2 & 11.0 \\
\hline Deposits & 40.9 & 39.9 & 42.8 & 48.2 & 53.6 \\
\hline
\end{tabular}

Source: calculated by the authors based on data [11; 14; 19-20; 40; 53].

Table 1.1 shows that banking sector assets to gross domestic product ratio in 2014-2018 increased from $87 \%$ to $113 \%$, and loans granted - from $69.8 \%$ to $74.8 \%$, but this growth was primarily due to the huge devaluation of hryvnia. At the beginning of 2015, the share of foreign currency assets in total assets was $43.73 \%$, while at the beginning of $2014-36.81 \%$. 
In addition, in 2014, the amount of highly liquid assets decreased by $3.76 \%$ (UAH 6.08 B) to UAH $155.64 \mathrm{~B}$ at the beginning of 2015 [11; 14; 40; 53]. Consequently, their share in the total assets of the banking sector was only $10.2 \%$. The total assets of banks in 2014 increased by UAH 112 B, or by $8 \%$ to UAH 1.5 trillion excluding currency fluctuations (according to the dollar exchange rate - UAH 7,993) - decreased by UAH 223 B (16 \%); the volume of lending increased by UAH $95 \mathrm{~B}$ or $10 \%$, and excluding currency fluctuations-decreased by UAH 139 B (15\%). Bank liabilities for 2014 increased by UAH 83 B (8 \%) to UAH 1.2 trln, and excluding currency fluctuations-decreased by UAH 230 B (21 \%). Deductions to reserves increased by 3.7 times compared to 2013 , and their share in total expenses increased from 16.7 to $39.3 \%$, and the level of capital adequacy decreased from 18.26 to $15,60 \%$ [11; 40; 53].

At the beginning of 2015 , commercial banks with private Ukrainian capital had almost $47 \%$ of the total assets of the banking sector, state-owned$22 \%$, with foreign capital (except Russian) - $17 \%$, with Russian capital $15 \%$. The equity to gross domestic product ratio for 2014-2018 decreased from $12.7 \%$ to $11.0 \%$. At the same time, the Ukrainian banking sector is not concentrated $[11 ; 14 ; 19-20 ; 40 ; 153]$, since the Herfindahl-Hirschman index has been consistently less than 0.1 for many years (Table 1.2).

Table 1.2

\section{Dynamics of the Herfindal-Hirschman index for the banking sector}

\begin{tabular}{|c|c|c|c|c|}
\hline $\begin{array}{c}\text { Years analyzed } \\
\text { (as of January 1) }\end{array}$ & \multicolumn{3}{|c|}{ Indicator } & Number of banks \\
\hline 2009 & 0.0394 & 0.042 & 0.0264 & 160 \\
\hline 2010 & 0.0389 & 0.0408 & 0.0271 & 163 \\
\hline 2011 & 0.0373 & 0.0274 & 0.0372 & 169 \\
\hline 2012 & 0.0257 & 0.0358 & 0.0249 & 173 \\
\hline 2013 & 0.0354 & 0.0361 & 0.0378 & 182 \\
\hline 2014 & 0.0375 & 0.0372 & 0.0492 & 189 \\
\hline 2015 & 0.0407 & 0.0408 & 0.0477 & 175 \\
\hline 2016 & 0.0426 & 0.0428 & 0.0484 & 175 \\
\hline 2017 & 0.047 & 0.0484 & 0.0448 & 175 \\
\hline 2018 & 0.0517 & 0.0546 & 0.0464 & 180 \\
\hline
\end{tabular}

Source: calculated by the authors based on data $[11 ; 19 ; 21 ; 40]$. 
This is accompanied by a deformation of the single financial and credit space, since centrifugal financial flows dominate, which is manifested in their excessive concentration in the Kyiv region. At the same time, according to the National Bank of Ukraine, banks from the largest group at the beginning of 2019 had $73 \%$ (UAH $961.1 \mathrm{~B}$ ) of the total assets of the banking sector, which is 9 percentage points more than at the beginning of 2018. Ukrainian banks remain small in relation to the size, needs of the economy, and trends in the development of the stock market versus the developed countries (Table 1.3).

This leads to the fact that the volume of loans granted does not meet the objectives of economic growth and the updated Framework for strategic reform of the state banking sector. In the structure of sources of investment financing for Ukrainian enterprises, the share of bank loans remains insignificant in comparison with developed countries $-8.8 \%$ (USA $-40 \%$, EU $-42 \%$, Japan - 65\%) [11; 19-20; 40; 53]. The capitalization of the banking sector remains quite low, which makes domestic banks increasingly dependent on foreign capital markets with a low degree of penetration into the stock market.

Table 1.3

Comparison of indicators of development of the banking sector in Ukraine with the leading countries

\begin{tabular}{|c|c|c|c|c|c|}
\hline Country name & $\begin{array}{c}\text { Number } \\
\text { of banks }\end{array}$ & $\begin{array}{c}\text { Number of } \\
\text { inhabitants, } \\
\text { mln persons }\end{array}$ & $\begin{array}{c}\text { Bank } \\
\text { assets, } \\
\text { EUR B }\end{array}$ & $\begin{array}{c}\text { Average } \\
\text { bank } \\
\text { assets, } \\
\text { EUR B }\end{array}$ & $\begin{array}{c}\text { Number of } \\
\text { inhabitants per } \\
\text { one bank, } \\
\text { thous. persons }\end{array}$ \\
\hline USA & 7770 & 310 & 10500 & 1.3 & 40 \\
\hline $\begin{array}{c}\text { EU-27 countries } \\
\text { including }\end{array}$ & 2300 & 465 & 32000 & 13.9 & 202 \\
\hline Germany & 342 & 83 & 8934 & 14.4 & 243 \\
\hline Italy & 201 & 58 & 2555 & 12.7 & 289 \\
\hline France & 352 & 60 & 6667 & 18.9 & 170 \\
\hline Russia & 956 & 142 & 1040 & 1.1 & 144 \\
\hline Ukraine & 180 & 45.4 & 128 & 0.7 & 252 \\
\hline
\end{tabular}

Source: calculated by the authors based on data [11; 19; 40; 53]. 
A full assessment of the level of financial stability of the banking sector and its financial security is not possible without a comprehensive analysis of the level of its individual components, in particular resource-creating one (Table 1.4). Thus, in 2018, the role of this component decreased as $[11 ; 14 ; 19]$ the structure of bank liabilities deteriorated; the growth rate of traditional sources of resource base formation decreased; the share of liabilities expressed by the balance of funds of individuals in general, as well as term funds of business entities and individuals decreased.

The share of individuals' funds in bank liabilities decreased from $33.9 \%$ to $31.6 \%$ in 2018 . The total authorized capital of banks decreased in 2018 by $2.7 \%$, to UAH $180.2 \mathrm{~B}$, and equity - by $23.1 \%$, to UAH $148 \mathrm{~B}$, as the National Bank of Ukraine during inspections revealed an artificial increase in the capital of a number of commercial banks and forced them to clear them of illiquid asset. In addition, the decrease in equity was caused by the liquidation of banks and loss-making activities of operating ones. At the same time, commercial banks, experiencing a lack of equity, are forced to resort more to internal and external borrowing, which increases their dependence on the latter and reduces both their financial security in the stock market and the financial stability of the banking sector as a whole.

Foreign currency liabilities at the beginning of 2019 accounted for $54.5 \%$ of total liabilities, which, in the face of huge currency risks caused by the curtailment of foreign currency lending to individuals and panicked depositors, also undermines the financial stability of the banking sector and the ability to ensure the security of its activities on the stock market. The volume of foreign capital in the authorized capital of Ukrainian banks increased from $27.6 \%$ in 2010 to $40.6 \%$ in 2014 or by 1.5 times. In 2014-2018, there was a general downward trend in this indicator. At the same time, at the beginning of 2019, this indicator was 1.5 times higher than the optimal value of the corresponding indicator as an incentive and satisfactory as a disincentive of the financial stability of the banking sector. However, the value of this indicator was twice lower than the critical one for indicators that destimulate the safety of the Bank's activities on the stock market. An important component of the financial stability of the banking sector is its deposit security, the level of which in 2018 is characterized by the data shown in Table 1.5. 
Table 1.4

Dynamics of financial security of a resource forming component of ensuring the security of bank activities in the stock market

\begin{tabular}{|c|c|c|c|c|c|}
\hline \multirow[t]{2}{*}{ Indicator } & \multicolumn{5}{|c|}{$\begin{array}{l}\text { Value of Indicators in the corresponding year } \\
\text { (as of January 1) }\end{array}$} \\
\hline & 2015 & 2016 & 2017 & 2018 & 2019 \\
\hline Liabilities, total, UAH mln. & 942088 & 1054280 & 1127192 & 1278095 & 1316852 \\
\hline Growth rate, $\%$ & 107.0 & 111.9 & 106.9 & 113.4 & 103.0 \\
\hline Capital, UAH mln. & 137725 & 155487 & 169320 & 192599 & 148023 \\
\hline Growth rate, \% & 119.6 & 112.9 & 108.9 & 113.8 & 76.9 \\
\hline Share in liabilities, $\%$ & 14.6 & 14.8 & 15.0 & 15.1 & 11.2 \\
\hline Authorized capital, UAH mln. & 145857 & 171865 & 175204 & 185239 & 180150 \\
\hline Growth rate, $\%$ & 122.4 & 117.8 & 102.0 & 105.7 & 97.3 \\
\hline Share in liabilities, $\%$ & 15.5 & 16.3 & 15.6 & 14.5 & 13.7 \\
\hline $\begin{array}{l}\text { Share of foreign capital in the } \\
\text { authorized capital of commercial } \\
\text { banks, \% }\end{array}$ & 40.6 & 41.9 & 39.5 & 34.0 & 32.5 \\
\hline Liabilities of commercial banks, mln. & 804363 & 898793 & 957872 & 1085496 & 1168829 \\
\hline Growth rate, $\%$ & 105.1 & 111.7 & 106.6 & 113.3 & 107.7 \\
\hline Share in liabilities, $\%$ & 85.4 & 85.3 & 85.0 & 84.9 & 88.8 \\
\hline $\begin{array}{l}\text { Funds of economic entities, } \\
\text { UAH mln. }\end{array}$ & 144038 & 186213 & 202550 & 234948 & 261372 \\
\hline Growth rate, $\%$ & 125.0 & 129.3 & 108.8 & 116.0 & 111.3 \\
\hline Share in liabilities, $\%$ & 15.3 & 17.7 & 18.0 & 18.4 & 19.9 \\
\hline $\begin{array}{l}\text { Term deposits of economic } \\
\text { entities, UAH mln. }\end{array}$ & 55276 & 74239 & 92786 & 104722 & 102527 \\
\hline Growth rate, $\%$ & 109.4 & 134.3 & 125.0 & 112.9 & 97.9 \\
\hline Share in liabilities, $\%$ & 5.9 & 7.1 & 8.2 & 8.2 & 7.8 \\
\hline Funds of individuals, UAH mln. & 270733 & 306205 & 364003 & 433726 & 416371 \\
\hline Growth rate, $\%$ & 128.9 & 113.1 & 118.9 & 119.2 & 96.0 \\
\hline Share in liabilities, $\%$ & 28.7 & 29.1 & 32.3 & 33.9 & 31.6 \\
\hline $\begin{array}{l}\text { Term deposits of individuals, } \\
\text { UAH mln. }\end{array}$ & 206630 & 237438 & 289129 & 350779 & 319121 \\
\hline Growth rate, $\%$ & 133.1 & 114.9 & 121.8 & 121.3 & 91.0 \\
\hline Share in liabilities, $\%$ & 21.9 & 22.5 & 25.7 & 27.5 & 24.2 \\
\hline $\begin{array}{l}\text { Effect of the banking sector in the } \\
\text { stock market, UAH mln. }\end{array}$ & 160897 & 178454 & 178909 & 204976 & 188949 \\
\hline Adequacy of regulatory capital, $\%$ & 20.83 & 18.90 & 18.06 & 18.26 & 15.60 \\
\hline
\end{tabular}

Source: calculated by the authors based on data [11; 14; 19-20; 40; 53] 
Table 1.5

Dynamics of indicators of deposit security of the banking sector as a security component of its activities in the stock market

\begin{tabular}{|l|c|c|c|c|c|}
\hline \multirow{2}{*}{\multicolumn{1}{|c|}{ Indicator }} & \multicolumn{5}{|c|}{ Value of Indicators in the corresponding year } \\
\cline { 2 - 6 } & $\mathbf{2 0 1 5}$ & $\mathbf{2 0 1 6}$ & $\mathbf{2 0 1 7}$ & $\mathbf{2 0 1 8}$ & $\mathbf{2 0 1 9}$ \\
\hline Deposits attracted, UAH mln & 442578 & 524974 & 603091 & 701625 & 720785 \\
\hline Growth rate, \% & 117.9 & 118.6 & 114.9 & 116.3 & 102.7 \\
\hline Ratio to gross domestic product, \% & 40.9 & 39.9 & 42.8 & 48.2 & 53.6 \\
\hline $\begin{array}{l}\text { Deposits of residents (except } \\
\text { corporations), UAH mln }\end{array}$ & 416650 & 491756 & 572342 & 669974 & 675093 \\
\hline Growth rate, \% & 124.4 & 118.0 & 116.4 & 117.1 & 100.8 \\
\hline Share, \% & 94.1 & 93.7 & 94.9 & 95.5 & 93.7 \\
\hline $\begin{array}{l}\text { Deposits of non-financial } \\
\text { corporations, UAH mln }\end{array}$ & 116105 & 153120 & 173319 & 195160 & 218724 \\
\hline Growth rate, \% & 122.5 & 131.9 & 113.2 & 112.6 & 112.1 \\
\hline Share in deposits of residents, \% & 27.9 & 31.1 & 30.3 & 29.1 & 32.4 \\
\hline Deposits of households, UAH mln & 275093 & 310390 & 369264 & 441951 & 418135 \\
\hline Growth rate, \% & 128.5 & 112.8 & 119.0 & 119.7 & 94.6 \\
\hline Share in deposits of residents, \% & 66.0 & 63.1 & 64.5 & 66.0 & 61.9 \\
\hline $\begin{array}{l}\text { Deposits of other financial } \\
\text { corporations, UAH mln }\end{array}$ & 19022 & 21799 & 20852 & 26174 & 29935 \\
\hline Growth rate, \% & 121.8 & 114.6 & 95.7 & 125.5 & 114.4 \\
\hline Share in deposits of residents, \% & 4.6 & 4.4 & 3.7 & 3.9 & 4.4 \\
\hline Deposits of non-residents, UAH mln & 25928 & 33218 & 30749 & 31651 & 34524 \\
\hline Growth rate, \% & 63.8 & 128.1 & 92.6 & 102.9 & 109.1 \\
\hline Share in total deposits, \% & 5.9 & 6.3 & 5.1 & 4.5 & 4.8 \\
\hline
\end{tabular}

Source: calculated by the authors based on data [11; 14; 19-20; 40; 53]

At the beginning of 2019 , the majority of deposits were on-demand deposits with maturities of up to one year (more than $2 / 3$ of the total volume of resident deposits), while only $4.1 \%$ of the total amount of these deposits had maturities of more than two years. At the same time, as of January 1,2016 , about $2 / 3$ of individuals' funds in commercial banks of Ukraine were placed with 20 institutions with the country's largest bank PJSC CB "PrivatBank" - attracting 22.6\% [24]. At the beginning of 2019, these indicators were $78.9 \%$ and $25.8 \%$, respectively. Deposit dollarization 
has significantly increased: as of January 1, 2018, it was $36.8 \%$, and as of January 1, 2019, it was $45.56 \%$. The decline in the deposit security of the banking sector occurred as a result of a huge outflow of hryvnia and foreign currency deposits in leading commercial banks, still continuing in the first half of 2019 (Table 1.6).

Table 1.6

Banks-leaders in the outflow of household deposits
for the 2nd quarter and the first half of 2019

\begin{tabular}{|c|c|c|c|c|c|}
\hline \multirow[t]{2}{*}{ Name of bank } & \multirow{2}{*}{$\begin{array}{c}\text { Deposit } \\
\text { portfolio as of } \\
\text { July } 1,2019, \\
\text { UAH million }\end{array}$} & \multicolumn{2}{|c|}{$\begin{array}{c}\text { Changes for the } \\
\text { second quarter of } \\
2019\end{array}$} & \multicolumn{2}{|c|}{$\begin{array}{c}\text { Changes for the } \\
\text { first six months } \\
\text { of } 2019\end{array}$} \\
\hline & & $\begin{array}{c}\text { million } \\
\text { UAH }\end{array}$ & $\%$ & $\begin{array}{c}\text { million } \\
\text { UAH }\end{array}$ & $\%$ \\
\hline $\begin{array}{l}\text { JSC "International } \\
\text { Investment Bank" }\end{array}$ & 1099,33 & $-1465,30$ & $-57,13$ & $-1777,61$ & $-61,79$ \\
\hline PJSC "Prominvestbank" & 1072,24 & $-1291,33$ & $-54,63$ & $-2088,73$ & $-66,08$ \\
\hline JSC "Ukreximbank" & 26175,56 & $-370,83$ & $-1,40$ & $-17,06$ & $-0,07$ \\
\hline PJSC "Bank Credit Dnipro" & 3632,87 & $-266,82$ & $-6,84$ & $-326,23$ & $-8,24$ \\
\hline PJSC CB "PrivatBank" & 177597,96 & $-228,35$ & $-0,13$ & 215,81 & 0,12 \\
\hline JSC "Sberbank" & 4822,35 & $-127,73$ & $-2,58$ & $-793,23$ & $-14,13$ \\
\hline JSC “Ukrsotsbank” & 514,21 & $-104,74$ & $-16,92$ & 212,41 & $-49,02$ \\
\hline JSC "Taskombank" & 8169,26 & $-39,36$ & $-0,48$ & 231,45 & 2,92 \\
\hline JSCB "Industrialbank" & 1520,62 & $-16,71$ & $-1,09$ & $-117,14$ & $-7,15$ \\
\hline JSC "Megabank" & 3787,17 & $-15,32$ & $-0,40$ & $-96,56$ & $-2,49$ \\
\hline
\end{tabular}

Source: calculated by the authors based on data [11;26; 43]

An increase in the number of insolvent banks indicates a decrease in the level of deposit security of commercial banks in 2014. Thus, at the beginning of 2015, there were 38 commercial banks that had been put into temporary administration or were in the process of liquidation. Along with this, depositors who had more than 200 thousand UAH on the accounts of insolvent banks "lost" UAH 14.4 B of their savings. A legal entity may lose almost as much if, during the liquidation of commercial banks the Deposit Guarantee Fund of Ukraine receives little funds from the sale of problem loans, collateral, and bank property [31]. 
Since loans account for the largest share of bank assets (in 2018, as in previous years, loans dominated in their structure (more than three-quarters of total assets), it is very important to maintain the credit security of the banking sector.

In 2010-2014, the volume of lending to the real sector of the economy by commercial banks to the gross domestic product first increased by $21.2 \%$ from $30.8 \%$ in 2010 to $52 \%$ in 2011 but in 2014 it decreased by $5.6 \%$ to $46.4 \%$. Such fluctuations have passed through significant increases in the volume of loans granted to business entities in 2010-2012, while the nominal gross domestic product grew much slower. However, at the end of 2012, the situation changed dramatically, which caused a change in the growth rate of this indicator. The global financial crisis forced commercial banks to stop lending for some time due to a lack of available financial resources, a lack of guarantees from borrowers, and growing amounts of non-repaid credit resources. At the same time, the nominal gross domestic product dropped from UAH 948 B in 2012 to UAH 913 B in 2013. Therefore, in 2013, on the general wave of decline in the gross domestic product, the volume of lending reached its peak, amounting to $52 \%$ of the gross domestic product. But in 2014, the expected decline took place, because the volume of gross domestic product increased significantly, and commercial banks were not able to resume lending in full. Considering the dynamics of this indicator, it can be determined that during the analyzed period it was in the safe zone (at least $30 \%$ ) but this was due to the inappropriate and uncontrolled provision of credit resources to business entities $[9 ; 14 ; 20]$.

The level of credit security of the banking sector as a component of ensuring the security of its activities in the stock market (Table 1.7) in 2018 decreased com-pared to the previous year, as the growth rate of loans provided by commercial banks decreased by 1.4 percentage points, and the share of overdue debt increased by 5.8 percentage points to $13.5 \%$. The total volume of loans granted increased by $10.4 \%$ at the beginning of 2019 compared to the previous year, to 1.006 trillion. $[11 ; 19 ; 53]$. At the same time, almost $100 \%$ of borrowers who receive income in hryvnia have become insolvent on foreign currency loans that overburden the banking sector.

The loan-to-deposit ratio of the banking sector is an indicator of the concentration of credit risks. On the eve of the crisis in August 2008, the loans to deposits ratio (in foreign currency) was at the level of $250 \%$. For 
Dynamics of indicators of loan security as a component of ensuring the security of its activities in the stock market

\begin{tabular}{|l|c|c|c|c|c|}
\hline \multirow{2}{*}{\multicolumn{1}{|c|}{ Indicator }} & \multicolumn{5}{|c|}{ Value of Indicators in the corresponding year } \\
\cline { 2 - 6 } & $\mathbf{2 0 1 5}$ & $\mathbf{2 0 1 6}$ & $\mathbf{2 0 1 7}$ & $\mathbf{2 0 1 8}$ & $\mathbf{2 0 1 9}$ \\
\hline Banking system assets, UAH mln & 942088 & 1054280 & 1127192 & 1278095 & 1316852 \\
\hline Growth rate, \% & 107.0 & 111.9 & 106.9 & 113.4 & 103.0 \\
\hline Loans granted, UAH mln & 755030 & 825320 & 815327 & 911402 & 1006358 \\
\hline Ratio to gross domestic product, \% & 69.8 & 62.7 & 57.9 & 62.7 & 74.8 \\
\hline Share in assets, \% & 80.2 & 78.3 & 72.3 & 71.3 & 76.4 \\
\hline $\begin{array}{l}\text { Loans granted to economic } \\
\text { entities, UAH mln }\end{array}$ & 508288 & 580907 & 609202 & 698777 & 802582 \\
\hline Growth rate, \% & 107.0 & 114.3 & 104.9 & 114.7 & 114.9 \\
\hline Share in assets, \% & 54.0 & 55.1 & 54.1 & 54.7 & 61.0 \\
\hline Loans to individuals, UAH mln & 186540 & 174650 & 161775 & 167773 & 179040 \\
\hline Growth rate, \% & 83.8 & 93.6 & 92.6 & 103.7 & 106.7 \\
\hline Share in assets, \% & 19.8 & 16.6 & 14.4 & 13.1 & 13.6 \\
\hline $\begin{array}{l}\text { Share of overdue loans in the } \\
\text { total loans, \% }\end{array}$ & 11.2 & 9.6 & 8.9 & 7.7 & 13.5 \\
\hline Investments in securities, UAH mln & 83559 & 87719 & 96340 & 138287 & 168928 \\
\hline $\begin{array}{l}\text { Provisions for active bank } \\
\text { operations, UAH mln }\end{array}$ & 148839 & 157907 & 141319 & 131252 & 204931 \\
\hline
\end{tabular}

Source: calculated by the authors based on data [11; 14; 19-20; 40; 53]

about two and a half years, this figure was at a much lower level $-130 \%$. At the beginning of the crisis (late 2008 - early 2009), this ratio increased even more, due to the mass withdrawal of deposits. In March 2009, the loanto-deposit ratio reached about $290 \%$ and decreased to $200 \%$ in September 2010 , as the credit crisis means that loans issued in foreign currency decreased, while deposits in foreign currency began to recover [9; 10-11].

One of the reasons for this gap in currencies at the level of banks' balance sheets was lower interest rates on foreign currency loans. This increased the vulnera-bility of the banking sector to crisis events. The domestic banking sector with the loan to deposit ratio of 1.7 in 2011 was significantly ahead of neighboring countries that went through the crisis of 2008-2009, and their sovereign credit rating is several steps higher than the domestic one 
(B2 from Moody's), for example, in Poland (A2) this indicator was 1.2, in the Czech Republic (A1) - 0.8, in Russia (Baa1) - 0.9, in Turkey (Ba2) - 1,0 $[11 ; 20 ; 53]$, and the level of dollarization of lending to the economy in 2018 increased from $34.8 \%$ to $48.0 \%$ [11; 19]. However, according to the National Bank of Ukraine, the excess liquidity of the banking sector at the beginning of 2019 was equal to UAH $30 \mathrm{~B}$, and the lack of trust between banks hinders the redistribution of liquidity and threatens the financial stability of the banking sector. At the same time, at the beginning of 2019, the value of the indicator describing the overall level of exposure of the banking sector to credit risk reached the minimum for the last three years $-86.6 \%$ (88.9 and $90.7 \%$ - at the beginning of 2017 and in 2018 respectively).

The analysis of the financial stability of the banking sector will be incomplete without assessing its investment component, which also decreased as a result of a significant decrease in the growth rate of commercial banks' investments in securi-ties, i.e., activity on the stock market (Table 1.8). At the same time, the share of in-vestments in securities in the assets of commercial banks of Ukraine in 2017-2018 increased from $10.8 \%$ to $12.8 \%$, while the volume of capital investments decreased by almost 2.5 times due to bank loans and other loans, which resulted in an almost twofold decrease in the share of the latter in the total volume of capital investments at the beginning of 2019. To a certain extent, the increase in the level of investment security of the banking sector is evidenced by a decrease in the share of foreign capital in the authorized capital of Ukrainian banks from almost $42 \%$ at the beginning of 2016 to $32.5 \%$ at the beginning of 2019 .

Debt security is also a significant component of financial stability in the bank-ing sector (Table 1.9). Thus, in 2012-2018, there was almost a twofold reduction in the external debt of the banking sector, which is due to a significant restriction on the access of Ukrainian commercial banks to international borrowing markets.

However, in the total volume of external debt, almost a third is shortterm debt, which, given the significant devaluation of the hryvnia, creates some tension in the foreign exchange market and increases the dependence of the banking sector on external borrowing.

At the same time, if in 2016 the share of external debt of the banking sector in the gross external debt of Ukraine was $16 \%$, in $2017-15.9 \%$, in $2017-14.8 \%$, that is, there is a tendency to reduce it. However, in 
Table 1.8

Dynamics of investment security indicators of the banking sector as a security com-ponent of its activities in the stock market

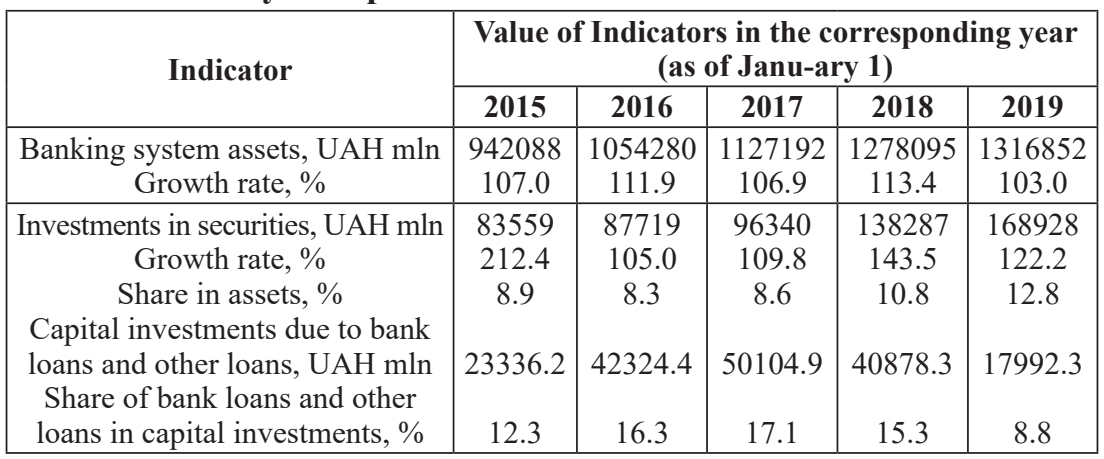

Source: calculated by the authors according to [11; 19-21; 53]

Table 1.9

Dynamics of investment security indicators of the banking sector as a security com-ponent of its activities in the stock market

\begin{tabular}{|c|c|c|c|c|c|c|c|c|}
\hline \multirow{2}{*}{ Indicator } & \multicolumn{70}{|c|}{ Years under study } \\
\cline { 2 - 10 } & $\mathbf{2 0 1 4}$ & $\mathbf{2 0 1 2}$ & $\mathbf{2 0 1 3}$ & $\mathbf{2 0 1 4}$ & $\mathbf{2 0 1 5}$ & $\mathbf{2 0 1 6}$ & $\mathbf{2 0 1 7}$ & $\mathbf{2 0 1 8}$ \\
\hline Short-term liabilities & 11723 & 9377 & 4731 & 4508 & 5786 & 4263 & 5438 & 5236 \\
\hline as \% of the total debt & 37.9 & 23.8 & 15.3 & 16.0 & 23.0 & 19.8 & 24.1 & 27.9 \\
\hline Loans & 9815 & 7850 & 2939 & 2773 & 3610 & 2648 & 3654 & 559 \\
\hline Currency and deposits & 1908 & 1480 & 1683 & 1662 & 2173 & 1612 & 1778 & 4677 \\
\hline Long-term liabilities & 19226 & 30094 & 26130 & 23611 & 19412 & 17290 & 17117 & 13516 \\
\hline as \% of the total debt & 62.1 & 76.2 & 84.7 & 84.0 & 77.0 & 80.2 & 75.9 & 72.1 \\
\hline $\begin{array}{c}\text { Bonds and other debt } \\
\text { securities }\end{array}$ & 6998 & 6124 & 4908 & 4672 & 3648 & 3301 & 5082 & 4365 \\
\hline Loans & 3214 & 3277 & 1823 & 1206 & 1216 & 1053 & 1753 & 2020 \\
\hline Currency and deposits & 9014 & 20740 & 19492 & 17806 & 14551 & 12939 & 10288 & 7131 \\
\hline
\end{tabular}

Source: calculated by the authors based on data [11; 14; 19-21; 53$]$

2013-2018, the volume of short-term external debt obligations of the banking sector almost doubled, and in 2016-2018 increased by 1.4 times.

The level of financial stability of the banking sector in 2014-2018 was also influenced by the dynamics of income and expenses of commercial 
banks (Table 1.10). Thus, during this period, the activities of commercial banks were profitable only in 2016-2017, while 2014-2015 and 2014 were characterized by their unprofitability.

Table 1.10

\section{Dynamics of income and expenses of commercial banks as a component of ensuring the security of their activities on the stock market}

\begin{tabular}{|l|c|c|c|c|c|}
\hline \multirow{2}{*}{\multicolumn{1}{|c|}{ Indicator }} & \multicolumn{5}{|c|}{ Value of Indicators in the corresponding year } \\
& \multicolumn{5}{|c|}{ as of January 1) } \\
\cline { 2 - 6 } & $\mathbf{2 0 1 5}$ & $\mathbf{2 0 1 6}$ & $\mathbf{2 0 1 7}$ & $\mathbf{2 0 1 8}$ & $\mathbf{2 0 1 9}$ \\
\hline Revenues, UAH mln & 136848 & 142778 & 150449 & 168888 & 210201 \\
Growth rate, \% & 95.7 & 104.3 & 105.4 & 112.3 & 124.5 \\
\hline Costs, UAH mln & 149875 & 150486 & 145550 & 167452 & 263167 \\
Growth rate, \% & 82.6 & 100.4 & 96.7 & 115.1 & 157.2 \\
\hline Operating results & -13027 & -7708 & 4899 & 1436 & -52966 \\
\hline Cost to income coverage ratio & 0.91 & 0.95 & 1.03 & 1.01 & 0.80 \\
\hline Return on assets, \% & -1.45 & -0.76 & 0.45 & 0.12 & -4.07 \\
\hline Return on equity, \% & -10.19 & -5.27 & 3.03 & 0.81 & -30.46 \\
\hline
\end{tabular}

Source: calculated by the authors based on data [11; 14; 19-21; 53]

Moreover, in 2018, taking into account the crisis manifestations of the banking sector's functioning, the total amount of losses was the largest for the period under review - almost UAH $53 \mathrm{~B}$ - and reached about a third of its authorized capital. At the same time, only 4/5 of the banking sector's expenses were covered by the revenues. This was primarily due to a significant increase in the growth rate of commercial banks' expenses (by 32.7 p.p.) over the growth rate of their income, which was largely caused by a negative revaluation of securities and an increase in reserves for possible losses. The financial result of the banking sector was negatively affected by losses of the banks classified as insolvent and where temporary administrations were introduced-UAH 19.9 B.Almost all major commercial banks ended 2018 with losses due to a deterioration in the quality of their loan portfolio. In the total volume of bank profits, UAH $4.37 \mathrm{~B}(80 \%)$ was accounted for by the 10 most profitable banks. Of the UAH $30 \mathrm{~B}$ of losses of the largest commercial banks $2 / 3$ were lost by state-owned banks, in particular, the JSC "Ukreximbank" (non-performing loans amounted to 
UAH 22.4 B) spent UAH 17 B on provisioning, and JSC "Oschadbank" UAH 12.2 B [11; 14; 20-24]. The share of profitable commercial banks in their total number in 2017-2018 decreased from 88.9 to $67.1 \%$, while the number of loss-making banks increased from 20 to 52 or from 11.1 to $32.9 \%$ of the total number of operating banks.

Positive values of return on assets and capital of commercial banks were ob-served only in 2016-2017 (and during this period it decreased almost fourfold), and the productivity of the banking sector significantly decreased. In the revenue part of domestic banks, interest income prevails, and expenditure-deductions to reserves, which indicates an insufficient level of financial stability of the banking sector in general and ensuring the security of its activities on the stock market in particular. To a large extent, this led to a reduction in the staff of commercial banks and a reduction in the level of remuneration - according to estimates [26], 30-35\% of bank employees became unemployed in 2017, and their salaries decreased by $10-30 \%$.

The post-crisis period forced commercial banks in Ukraine to maintain their financial security to resort to conservative credit policy, reducing their own costs by reducing the branch network. The state also implemented an anti-crisis policy, which included the recapitalization of large systemically important banks. Excessive segmentation of the banking sector doesn't also increase the level of financial stability of the banking sector, which is reflected in the growth of differences between the groups of banks allocated by the National Bank of Ukraine (Table 1.11).

Also public, private (with domestic and foreign capital) banks, in particular, in the implemented policy, access to refinancing by the National Bank of Ukraine and foreign markets.

In addition, the financial stability of the banking sector has been reduced due to external factors such as:

first, the deterioration of the financial condition of economic entities in most types of economic activity;

second, the stringent conditions of foreign borrowing;

third, the growth of unemployment;

fourth, the opening of opportunities (since July 2017) for Ukrainians to invest in securities abroad (under a simplified procedure of up to 50 thousand dollars per year) against the background of high volatility and 
Table 1.11

The role of cluster groups of banks in the financial security

of the banking sector as a whole and the security of its activities

on the stock market in particular

\begin{tabular}{|c|c|c|c|c|c|c|c|c|}
\hline \multirow{3}{*}{ Indicator } & \multicolumn{8}{|c|}{ Value of the indicator in the corresponding year (as of January 1) } \\
\hline & \multicolumn{4}{|c|}{2018} & \multicolumn{4}{|c|}{2019} \\
\hline & $Q_{1}$ & $Q_{2}$ & $Q_{3}$ & $Q_{4}$ & $Q_{1}$ & $Q_{2}$ & $Q_{3}$ & $Q_{4}$ \\
\hline Assets & 69.77 & 14.54 & 6.41 & 9.28 & 72.99 & 14.44 & 7.49 & 5.07 \\
\hline Liabilities & 70.30 & 14.38 & 6.72 & 8.60 & 72.81 & 14.98 & 7.56 & 4.65 \\
\hline Capital & 66.13 & 15.62 & 4.30 & 13.94 & 74.45 & 10.22 & 6.93 & 8.40 \\
\hline
\end{tabular}

Source: calculated by the authors according to [11;26; 53$]$

unpredictability of the Ukrainian stock market, which causes an additional analysis of the relevance of stability and security of the banking sector environment with an indicative assessment of the stock market development.

\section{Identification of interinfluences and interconnections of stability} of the security environment of development of the banking sector and exchange market as financial donors for the implementation of the new "green" provisions of economic development

The national stock market is currently going through a difficult period - it is significantly falling behind the stock markets of industrialized countries, which does not allow it to effectively perform the core functions, in particular, to widely involve commercial banks in the circulation of securities, including domestic government bonds (debt securities that are sold by the government to primary dealers and their clients in the primary market to finance the needs of the state budget).

The rapid deterioration of the military-political and economic situation in Eastern Ukraine in August 2014, as well as the slowdown in necessary structural reforms and further devaluation of the hryvnia, led to a sharp change in investor sentiment and expectations $(-12 \%$ in the third quarter, after $+20 \%$ in the second and +12 in the first quarter on the UX index $[11 ; 26])$. For the fourth quarter, the key Ukrainian indicator largely consisting of enterprises located on the territory not controlled by Ukraine, fell by another $4 \%[11 ; 31]$. Another of the main problems of the Ukrainian stock market is the lack of interest in the 
country's population and the high risk of assets due to the instability of the situation in the financial market.

Regarding the trends in the development of the stock market of Ukraine, from its inception to the present day, scientists $[6 ; 17 ; 28]$ identify five major stages of its development: formation (1991-1994), development and mass privatization (1995-1999), improvement and implementation of international standards (2000 - the first half of 2008), the financial crisis (the second half of 2008-2009), modernization (2010 - present).

There are three stock market models in the world depending on the banking or non-banking nature of financial intermediaries $[1-2 ; 5 ; 7]$ : 1) non-banking model (USA) - non-bank securities companies act as intermediaries; 2) banking model (Germany) - banks act as intermediaries; 3) mixed model (Japan) - both banks and non-bank companies act as intermediaries.

The architecture of the Ukrainian stock market simply copied other models (primarily the US model), for the introduction of which there were no institutional conditions. "Due to the fact that the development of the Ukrainian stock market fails to meet the interests of potential participants, the Ukrainian economy is constantly losing sources of additional funds as the population does not participate in investment processes" [8], and accordingly, there is a fairly low level of participation of banks in its work.

We will further consider how the above processes affect the stock market of Ukraine. So, today the results of its work are very ambiguous. On the one hand, the positions of all financial institutions have deteriorated significantly, and on the other hand, they have passed through the crisis and war. Against the background of declining investment attractiveness of Ukraine, the process of capital inflow from abroad was stopped, and commercial banks, in particular the PJSC CB "PrivatBank", in order to expand the Bank's corporate client's opportunities to attract capital investments and implement large-scale investment projects, received a license from the National Securities and Stock Market Commission to conduct professional activities in the stock market-underwriting. The volume of trading on the securities market is shown in Figure 2.1. Thus, in 2015, the volume of trading on the stock market amounted to UAH $1676.97 \mathrm{~B}$, while in 2014 this figure was UAH $2530.87 \mathrm{~B}$. The decrease in trading volume in 2015 was due to a decrease in operations on securities on the OTC market to UAH 1,213. 
$54 \mathrm{~B}$ as a result of the introduction of a special tax on transactions involving the alienation of securities and operations with derivatives. At the end of 2016, the stock market grew by $39.06 \%$ compared to 2015 and amounted to UAH $2331.95 \mathrm{~B}$. Although there is an increase in the share of transactions with securities traded on the exchange market, about $73.43 \%$ of all the transactions were carried out in the over-the-counter segment of the stock market. In 2017, the volume of trading on the stock market decreased by $6.83 \%$ compared to 2016 and amounted to UAH $2172.67 \mathrm{~B}$, and at the end of 2018 , the volume of trading still decreased by $2.07 \%$ compared to 2017 and amounted to UAH 2127.55 B.

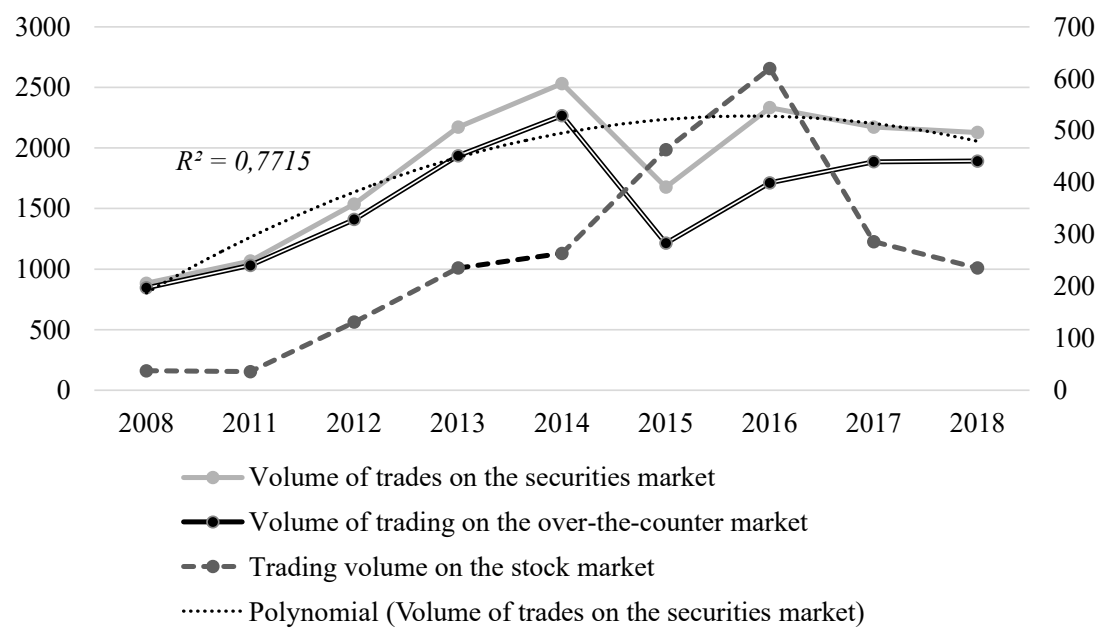

Figure 2.1. Dynamics of trading volumes on the stock market, UAH B Source: calculated by the authors according to [18; 21; 53]

We can observe the dynamics of trading volumes on the stock market and gross domestic product according to Figure 2.2.

Since 2011, there has been a steady advance in the pace of securities trading volumes compared to the dynamics of the gross domestic product. The stock market grew faster than the gross domestic product: the volume of trading on the securities market in 2013-2014 exceeded the indicator of the country's gross domestic product almost twice - this indicates the 


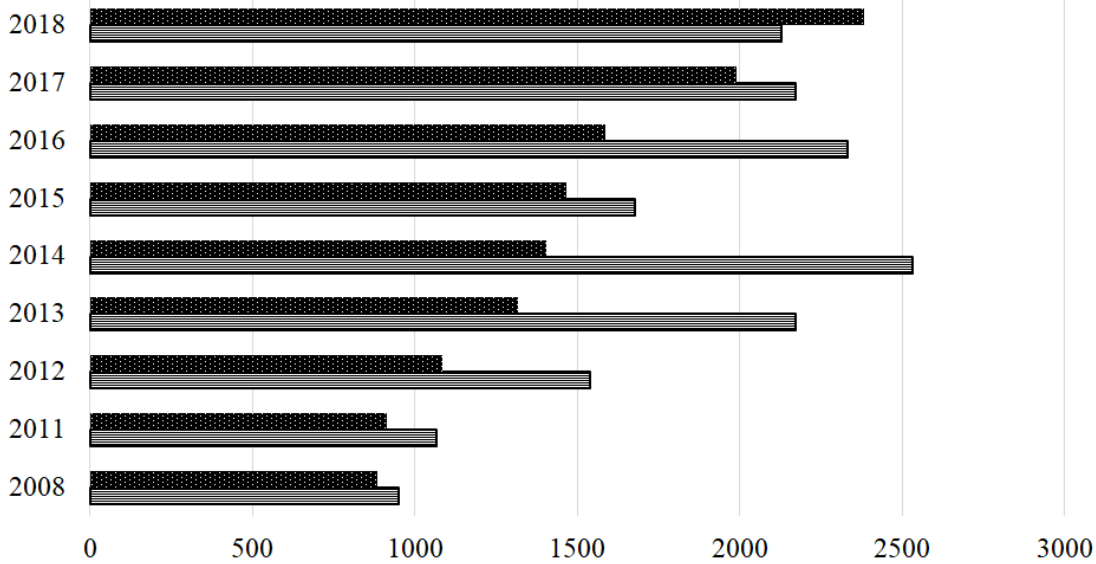

Gross Domestic Product 目 Volume of trading on the stock market

Figure 2.2. Comparison of trading volumes on the stock market and gross domestic product, UAH B

Source: calculated by the authors according to [19; 21; 53]

development of the state's economy in general and the development of the stock market in particular. In 2015, the stock market trade volume exceeded this indicator by UAH 222 B, and in 2015 exceeded the previous year's figure by UAH 193.21 B. However, during 2015-2017, the gross domestic product to stock market trading ratio has a negative trend, and in 2016, there is an increase in the gross domestic product compared to the volume of trading on the stock market.

One of the stock market efficiency indicators is the development of its orga-nized sector. Thus, the share of the exchange market in the total volume of trading on the stock market is quite low. Since 2015, there has been a decrease in the share of the exchange market in the total stock market trading volume. Compared to 2012 and 2016, this indicator is growing moderately, with an increase of $15.85 \%$. In 2016, the share of the exchange market in the total volume of the stock market trading decreased to $26.59 \%$, in $2017-13.35 \%$, and in $2018-11.18 \%$. Figure 2.3 shows the volume of executed exchange contracts with securities on the trade organizers. 


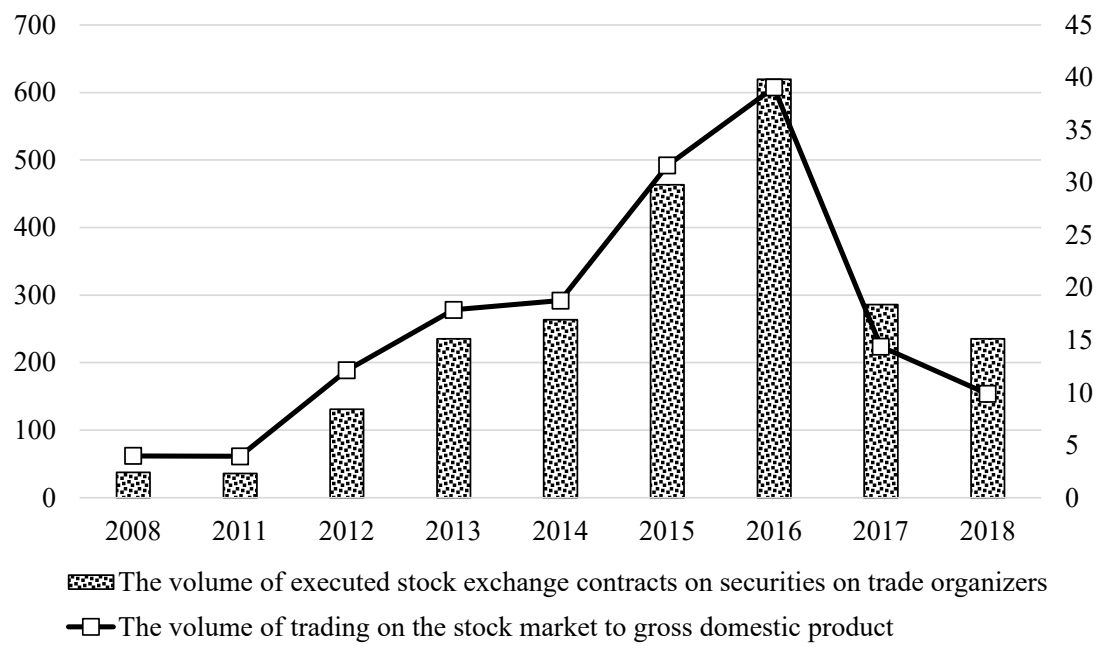

Figure 2.3. Dynamics of the volume of executed securities exchange contracts on trade organizers, UAH B

Source: calculated by the authors according to [19; 21; 26; 53$]$

In 2013-2015, the stock market was characterized by a fairly high activity of the exchange segment. According to the results of 2015, the volume of the executed securities exchange contracts on trade organizers doubled and amounted to UAH $463.43 \mathrm{~B}$, while in 2014 this figure was UAH 263.67 B.

This indicator was the highest in 2016 - UAH 619.7 B. In 2016, as compared to the previous year, the volume of securities exchange contracts on trade organizers increased by $33.72 \%$ and amounted to UAH 619.70 B which is equivalent to $39.55 \%$ of the gross domestic product of Ukraine. In 2017, there was a decline in the stock market segment. Compared to 2016, the volume of exchange contracts with securities on trade organizers in 2017 decreased by $53.81 \%$ to UAH $286.21 \mathrm{~B}$, which is equivalent to $14.46 \%$ of gross domestic product. In 2018, there is a decline in the stock market segment. In comparison with the indicator of 2017, the volume of securities exchange contracts on trade organizers in 2018 decreased by $17.75 \%$ to UAH $235.41 \mathrm{~B}$, which is equivalent to $9.88 \%$ of gross domestic product. 
It should be noted that the Ukrainian stock market uses a wide range of financial instruments, such as shares, state and municipal domestic loan bonds, business bonds, treasury bonds, savings certificates, state and compensation certificates, housing checks, investment certificates, and foreign loan bonds. Changes in the structure of trading volume on the stock market with distribution by financial instruments are shown in Table 2.1.

Considering data on the structure of the trading volume in the stock market for financial instruments in the 2008-2018, we see different tools were favored in different years: in 2008-2011 mostly stocks and bonds were used; since 2012 state bonds of Ukraine became more popular - in 2014 they amounted to $48 \%$ of the total, in 2015 investment certificates took first place. In 2018, the volume of trading was dominated by shares and government bonds of Ukraine. Ukrainian government bonds dominated the exchange market and in 2018 their share exceeded $89 \%$. Government bonds of Ukraine took the leading position among financial instruments in terms of trading volumes on the exchange market - Table 2.2. The volume of trades on trade organizers during 2014-2018 is shown in Table 2.3.

Our country is one of the few where such a large number of stock exchanges operate - "a large number of exchanges does not guarantee high quality of services, but on the contrary, leads to the decentralization of supply and demand for securities, provokes the process of manipulating prices in the market, leads to the establishment of various rules for the conclusion and execution of exchange contracts. The presence of such a large number of trading platforms makes it difficult to control operations with securities, promotes manipulation of their value, and disorients commercial banks in choosing a trading platform" [33], significantly complicating the methods and technologies for ensuring the security of the banking sector in the stock market. Thus, the organized market in 2014 demonstrated consolidation of securities trading - about $98.25 \%$ of the exchange-traded securities contracts were focused on three stock exchanges: "Perspektiva" (55.21\%), PFTS (33.93 \%) and "Ukrainian Exchange" (9.11\%), and in 2015, about $91.01 \%$ of exchange-traded securities contracts were focused on only two stock exchanges: "Perspektiva" (67.23\%) and PFTS (23.78\%).

Growth dynamics in the volume of exchange-traded contracts in 2016 were demonstrated by the Stock Exchange "Perspektiva" (79.15\%) and PFTS (15.47\%) stock exchanges. At the same time, trading volumes at the 
Serhii Petrukha, Mykola Korolenko

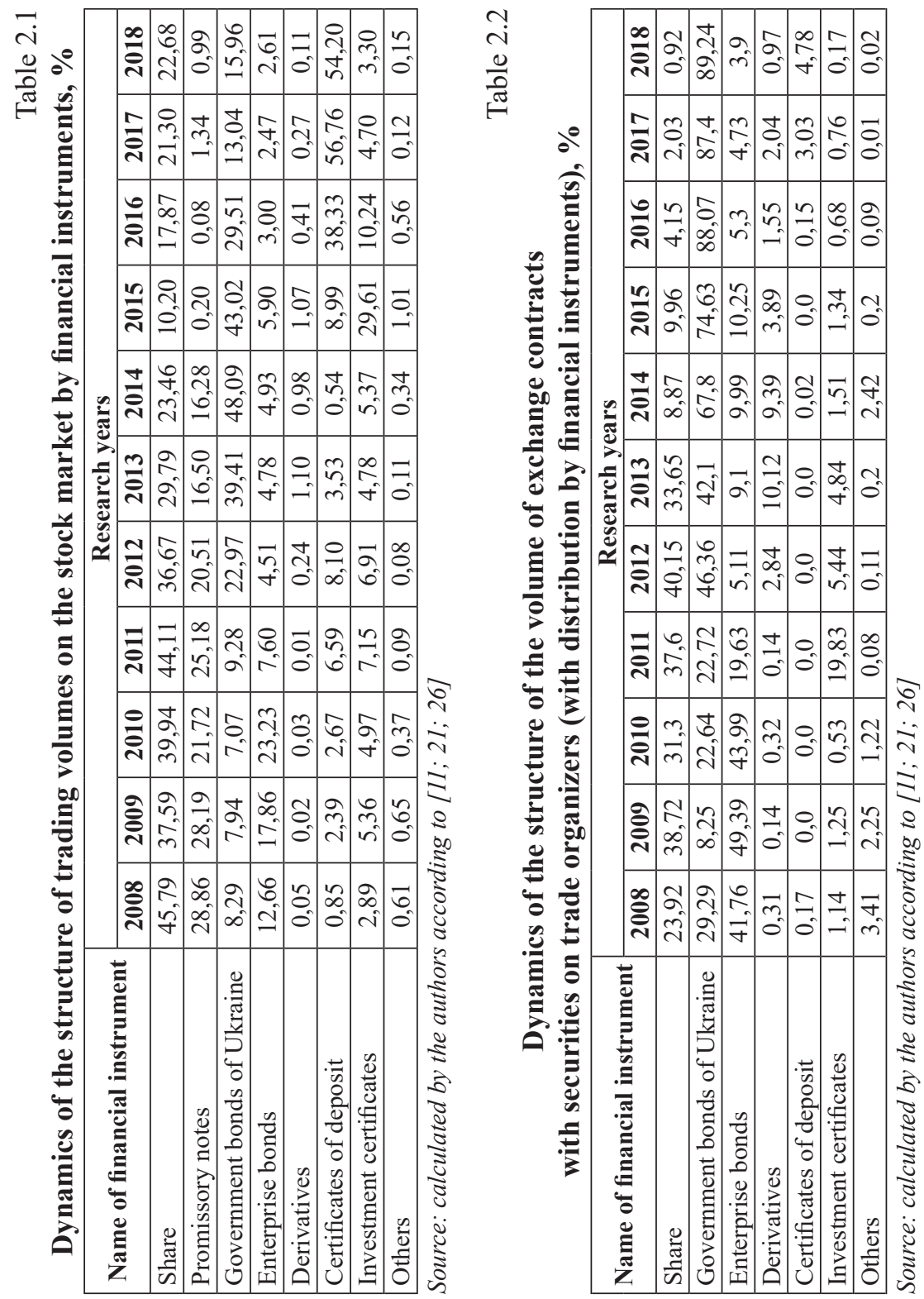


Table 2.3

Dynamics of trading volumes at trade organizers, UAH B

\begin{tabular}{|l|c|c|c|c|c|}
\hline \multirow{2}{*}{ Name of the trade organizer } & \multicolumn{5}{|c|}{ Research years } \\
\cline { 2 - 7 } & $\mathbf{2 0 1 4}$ & $\mathbf{2 0 1 5}$ & $\mathbf{2 0 1 6}$ & $\mathbf{2 0 1 7}$ & $\mathbf{2 0 1 8}$ \\
\hline Stock Exchange "Perspektiva" & 145563,9 & 311585,7 & 490458,1 & 220332,2 & 13657,62 \\
\hline PFTS Stock Exchange & 89463,95 & 110225,5 & 95881,73 & 53181,8 & 96719,2 \\
\hline Ukrainian stock exchange & 2423,66 & 10890,31 & 8565,89 & 6692,36 & 3531,2 \\
\hline $\begin{array}{l}\text { Kyiv International Stock } \\
\text { Exchange }\end{array}$ & 1967,6 & 10000 & 8656,5 & 6200 & 3000 \\
\hline Ukrainian Universal Exchange & 1458,6 & 9561 & 9000 & 186 & 2100 \\
\hline $\begin{array}{l}\text { PJSC "Eastern European } \\
\text { Stock Exchange" }\end{array}$ & 300,5 & 280 & 90 & 96 & 88 \\
\hline $\begin{array}{l}\text { Ukrainian Interbank Currency } \\
\text { Exchange }\end{array}$ & 95 & 600 & 87 & 92 & 90 \\
\hline Ukrainian stock exchange & 83 & 60 & 93 & 85 & 81 \\
\hline $\begin{array}{l}\text { Commodity Exchange } \\
\text { "INNEX" }\end{array}$ & 70 & 80 & 82 & 83 & 86 \\
\hline $\begin{array}{l}\text { Ukrainian International Stock } \\
\text { Exchange }\end{array}$ & 60 & 72 & 76 & 87 & 32 \\
\hline
\end{tabular}

Source: calculated by the authors according to [11;21;26]

trade organizers - UMFB, UFB and INNEX - have significantly decreased. The largest volume of financial instruments trading during 2016 was recorded with government bonds of Ukraine - UAH $545.77 \mathrm{~B}(88.07 \%$ of the total volume of exchange-traded contracts on trade organizers in 2016). During 2017, out of ten stock exchanges operating in Ukraine, only two - PFTS Stock Exchange and Stock Exchange "Perspektiva" - demonstrated significant trading volumes, controlling more than $95.56 \%$ of the value of exchangetraded contracts. During 2018, most stock exchanges show a decrease in the total volume of exchange-traded contracts. The reason for such a drop is a sharp decrease in non-market transactions in the organized market. In addition, three out of eight stock exchanges did not meet the requirements for the minimum number of available trading days during the year with growth observed only at PFTS. The largest volume of financial instruments trading during 2018 was recorded with government bonds of Ukraine - UAH $210.08 \mathrm{~B}$ (89.24 \% of the total volume of exchange-traded contracts in 2018). 
In 2018 the highest demand in the stock market by volume of exchangetraded contracts was for securities of the twenty issuers [20-21; 26]: bonds of the public joint-stock company "Ukrainian Railway" (trade organizers - PFTS and "Perspektiva"), bonds of the PJSC "Pharmaceutical Firm "Darnytsia" (PFTS), a futures contract of the public joint-stock company "Ukrainian Exchange" ("UB"), shares of the public joint-stock company "Centrenergo" ("UB", PFTS and "Perspektiva"), optional certificate of "TMO "Liko-holding" ("UB", PFTS and "Perspektiva"), bonds of the limited liability company "SK-AGRO" ("Perspektiva"), bonds of the public joint-stock company "Tascombank" ("Perspektiva" and PFTS), bonds of the PJSC "Poznyakizhilstroy" (KMFB and PFTS), bonds of the JSC "Trest Zhilstroy-1" ("Perspektiva"), shares of the public jointstock company "Motor Sich" ("UB" and PFTS), bonds of PrJSC "NEO Vita" (KMFB), the investment certificate of the limited liability company "Asset Management Company "Holding Group" (KMFB, "Perspektiva" and "UB"), shares of the public joint-stock company "Raiffeisen Bank Aval" ("UB", PFTS and "Universal"), bonds of the limited liability company "RUSH" (PFTS and "Perspektiva"), bonds of the limited liability company "Burat-agro" ("Perspektiva"), optional certificate of the limited liability company "Market-1" ("Universal"), bonds of the additional liability company "Zhilstroy-2" ("Perspektiva" and "UB"), bonds of the PJSC "Alfa-Bank" ("Perspektiva", PFTS and "UB"), bonds of the limited liability company "Logistik-agro" ("CMFB"), shares of the public jointstock company "Ukrnafta" ("UB", PFTS and "Universal").

The most demanded on the exchange market in 2018 by the number of ex-change-traded contracts were the securities of the following twenty issuers [11;20-21;26]: shares of the public joint-stock company "Centrenergo" (trade organizers - "UB", PFTS and "Perspektiva"), futures contract of the public joint-stock company "Ukrainian Exchange" ("UB”), shares of the public joint-stock company "Ukrnafta" ("UB", PFTS and "Universal”), shares of the public joint-stock company "Raiffeisen Bank Aval" ("UB", PFTS and "Universalna"), shares of the public joint-stock company "Motor Sich" ("UB" and PFTS), investment certificates of the PJSC "KINTO" ("UB"), shares of the public joint-stock company "Donbassenergo" ("UB", PFTS, "Universal" and "Perspektiva"), optional certificate of the limited liability company "Market-1" ("Universal”), shares of the public joint-stock 
company "Alchevsk Iron and Steel Works" ("UB", PFTS and INNEKS), shares of the PJSC "MK "Azovstal" ("Perspektiva" and INNEKS), shares of the public joint-stock company "Kriukovsky Car Building Plant" ("UB" and PFTS) and shares of the public joint-stock company "Avdiivka Coke Plant" ("UB", PFTS and "Perspektiva"), the option of the public jointstock company "Ukrainian exchange" ("UB"), shares of the public jointstock company "Ukrtelecom" ("UB", PFTS, "Perspektiva" and INNEKS), shares of the PJSC "Kovelmoloko" ("UB"), shares of the public jointstock company "Ukrsotsbank" ("UB", PFTS and "Perspektiva"), shares of the public joint-stock company "Turboatom" ("UB" and PFTS), shares of the joint-stock bank "Ukrgasbank" ("UB" and "Perspektiva"), shares of the public joint-stock company "Yenakiyevo Iron and Steel Works" ("UB", PFTS and "Universal"), shares of the public joint-stock company "Automotive Company "Bogdan Motors" ("UB" and INNEKS).

Below is the list of issuers whose securities were most demanded in the OTC market $[11 ; 20-21 ; 26]$ : shares of the private joint-stock company "Financial Company "Troika Invest", private joint-stock company "OIL Trade", private joint-stock company "Ukrprom-invest", public joint-stock company "Power Electronic Control Devices", public joint-stock company "Invest Code", private joint-stock company "VO "Promtekhmontazh", private joint-stock company "NK "Oil City", public joint-stock company "Primadonna", private joint-stock company "OST-invest", public jointstock company "Ukrnafta", private joint-stock company "FC "Credit service", public joint-stock company "UkrSibbank", public joint-stock company "King's Ice", private joint-stock company "Medical Tomograph Investment", private joint-stock company "Plant Radar", public joint-stock company "Dniproazot", corporate bonds of the limited liability company "DTEK Dobropillia-Coal", the investment certificates of the limited liability company "AMC "Lemaco Asset Management", the limited liability company "Asset Management Company "Holding Group" and the limited liability company "AMC "Investment House "Megapolis".

Information about the number of issues of securities in circulation on the stock market characterizes its condition. As of December 31, 2018, the number of issues of securities circulating on the stock market was 19904, of which $9.26 \%$ were admitted to trading on stock exchanges (Figure 2.4). 
The peculiarity of banks activity on the stock market is that they carry out op-erations on it according to the general rules that apply to all participants of the stock market, but they must also comply with additional rules established by the National Bank of Ukraine. When performing operations on the stock market the PJSC CB "PrivatBank" must build relationships with clients based on the principles of good faith, honesty, completeness of disclosure of necessary information, and execution of client's orders solely in their interests.

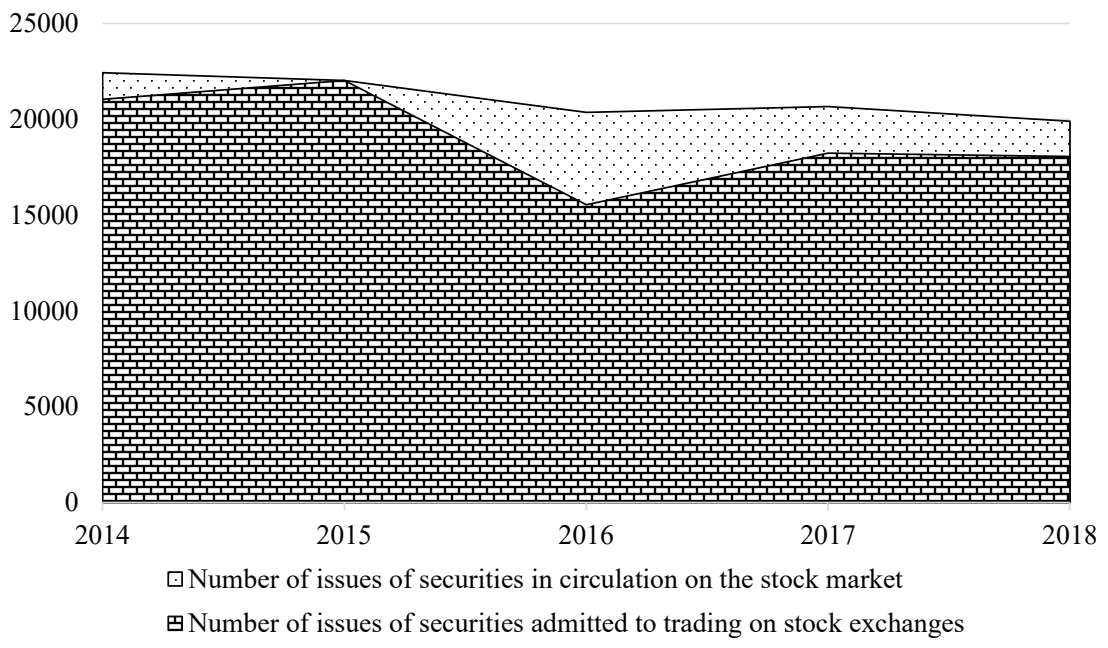

\section{Figure 2.4. Dynamics of quantitative values of issues of securities circulated on the stock market}

Source: calculated by the authors according to [11;21;26]

Factors affecting the activities of the PJSC CB "PrivatBank" on the stock market are shown in Table 2.4.

According to the Law of Ukraine "On banks and banking activities" [29] and the practice of statistical reports of the National Securities and Stock Market Commission [21], we have identified three conditional areas of activity of the banking sector as a whole and the PJSC CB "PrivatBank" in the stock market as an Issuer, investor and professional participant. Ukrainian banks are among the top ten issuers that have registered the 
Table 2.4

Factors that determine the activity of the PJSC CB "PrivatBank" on the stock market

\begin{tabular}{|c|c|c|}
\hline $\begin{array}{l}\text { Clusters } \\
\text { of } \\
\text { factors }\end{array}$ & Factor name & $\begin{array}{c}\text { Characteristics of the impact on the security system of } \\
\text { bank activities on the stock market }\end{array}$ \\
\hline \multirow{4}{*}{ 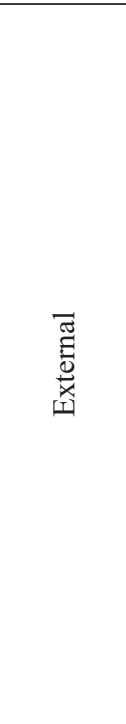 } & Economic & $\begin{array}{l}\text { Regulation of the bank activities in the form of economic } \\
\text { regulations and monetary policy of the National Bank } \\
\text { of Ukraine, which affects the bank's offer on the stock } \\
\text { market. The establishment (cancellation) of various tax } \\
\text { incentives and incentives for stock market entities that } \\
\text { en-courage (restrain) the use of securities as financing } \\
\text { tools to improve the investment climate in the state, } \\
\text { attract foreign investment and flexible state investment } \\
\text { policy contribute to bank activity in the stock market }\end{array}$ \\
\hline & Market & $\begin{array}{l}\text { The complexity and multiplicity of barriers to enter the } \\
\text { stock market, the high level of competition in it, reduces the } \\
\text { bank interest in developing activities in it, and vice versa }\end{array}$ \\
\hline & Regulatory & $\begin{array}{l}\text { Consistency of the system of legal support for the stock } \\
\text { market and the regulatory framework for the financial } \\
\text { security of banking activities, their compliance with } \\
\text { international requirements and market laws, which affects } \\
\text { the risk of operations for the bank }\end{array}$ \\
\hline & Political & $\begin{array}{l}\text { The unstable political situation in the country, the low } \\
\text { level of people's trust in authorities, as well as frequent } \\
\text { political conflicts increase the risk of securities trading }\end{array}$ \\
\hline \multirow{4}{*}{ 蔦 } & $\begin{array}{l}\text { Resource } \\
\text { capabilities }\end{array}$ & $\begin{array}{l}\text { Growth/decrease in the amount of equity capital, inability } \\
\text { to attract long-term deposit funds, complication of access } \\
\text { to emission sources }\end{array}$ \\
\hline & $\begin{array}{l}\text { Investment } \\
\text { policy of the } \\
\text { bank }\end{array}$ & $\begin{array}{l}\text { formation of a particular type of portfolio, using effective } \\
\text { methods of analysis and methods, and tools to minimize } \\
\text { the risks of securities trad-ing }\end{array}$ \\
\hline & $\begin{array}{l}\text { Technical- } \\
\text { technological }\end{array}$ & $\begin{array}{l}\text { Availability (absence) of the latest means of transmitting } \\
\text { information, Internet resources, financial innovations, etc }\end{array}$ \\
\hline & $\begin{array}{c}\text { Personnel } \\
\text { potential }\end{array}$ & $\begin{array}{l}\text { Availability (absence) of qualified managers with up-to- } \\
\text { date securities trading skills }\end{array}$ \\
\hline
\end{tabular}

Source: compiled by the authors $[3 ; 16 ; 24 ; 36]$

largest share issues. The volume of shares issued by these issuers amounted to $69.54 \%$ of the total volume of share issues registered in 2018 by the National Securities and Stock Market Commission [21]. It should be noted 
that for a long period of time, banks did not raise capital through the issue of their own financial instruments such as shares and bonds. Table 2.5 shows the volume of shares issued by banks during 2014-2018.

Table 2.5

Dynamics of share issue by Ukrainian banks, UAH B

\begin{tabular}{|l|c|c|c|c|c|}
\hline \multirow{2}{*}{ Indicator } & \multicolumn{5}{|c|}{ Years under study } \\
\cline { 2 - 6 } & $\mathbf{2 0 1 4}$ & $\mathbf{2 0 1 5}$ & $\mathbf{2 0 1 6}$ & $\mathbf{2 0 1 7}$ & $\mathbf{2 0 1 8}$ \\
\hline $\begin{array}{l}\text { Total volume of shares issued } \\
\text { by economic entities }\end{array}$ & 58.16 & 15.84 & 64.23 & 144.35 & 122.30 \\
\hline Volume of shares issued by banks & 36.04 & 3.75 & 32.27 & 36.41 & 88.28 \\
\hline Share, \% & 61.09 & 23.67 & 50.25 & 25.22 & 72.18 \\
\hline
\end{tabular}

Source: calculated by the authors according to $[11 ; 21 ; 26]$

The nominal registered value of the issued share capital of the PJSC CB "PrivatBank" as of December 31, 2018 was UAH 206060 mln out of the total number of ordinary shares accepted for issue, it was 735.93 million shares with a nominal value of UAH 280 per share. After the nationalization of the PJSC CB "PrivatBank" in December 2016 the government of Ukraine, represented by the Ministry of Finance of Ukraine, is its sole shareholder. Analyzing the activities of other banks in the stock market, it should be noted that during 2014-2018 their share in the total volume of participants in the securities market changed dramatically, which affected the structure of registered bond issues. For 2017, the volume of issue of bonds didn't show positive growth dynamics - registered bond issue in the amount of UAH 4,8 B (21.27\% of the total), while in 2018 their issuing activity in the corporate bond market has decreased. In the structure of the volume of corporate bond issues registered by the National Securities and Stock Market Commission [21], banks have not registered any bond issues (Table 2.6).

By carrying out investment activities on the stock market the PJSC CB "PrivatBank" aims [24]: to make a profit from its own investments in securities due to the interest received by the Bank, dividends and growth in the exchange value of securities; to make a profit from providing services to clients on operations with securities; to expand the Bank's sphere of influence and attract new clients through participation in the capitals of enterprises and organizations. 


\section{Dynamics of quantitative and structural values of bond issuance by banks, UAH mln.}

\begin{tabular}{|l|c|c|c|c|c|}
\hline \multirow{2}{*}{ Indicator } & \multicolumn{5}{c|}{ Years under study } \\
\cline { 2 - 6 } & $\mathbf{2 0 1 4}$ & $\mathbf{2 0 1 5}$ & $\mathbf{2 0 1 6}$ & $\mathbf{2 0 1 7}$ & $\mathbf{2 0 1 8}$ \\
\hline $\begin{array}{l}\text { Volume of bonds issued } \\
\text { by banks }\end{array}$ & 13893.5 & 11770.0 & 8040.0 & 4800.0 & not available \\
\hline $\begin{array}{l}\text { Total volume of bonds } \\
\text { issued by business entities }\end{array}$ & 35914.44 & 51386.61 & 42472.52 & 29009.22 & 11421.17 \\
\hline $\begin{array}{l}\text { Share of the Bank's bonds } \\
\text { in the total volume of their } \\
\text { issue, \% }\end{array}$ & 38.68 & 22.9 & 18.93 & 21.7 & not available \\
\hline Liabilities of banks & 898793.1 & 957872 & 1085496 & 1168829 & 1157656 \\
\hline $\begin{array}{l}\text { Share of bonds in total } \\
\text { liabilities of banks, \% }\end{array}$ & 1.59 & 1.27 & 0.76 & 0.73 & not available \\
\hline
\end{tabular}

Source: calculated by the authors according to [23; $65 ; 71]$

As seen from Table 2.7 only in 2016 the banks significantly increased their portfolio of securities (except for shares) - this growth was mainly due to government bonds, in 2017 the increase in the portfolio of securities of banks and shares, and other securities) almost did not occur.

The structure of the securities portfolio in 2018 has increased relatively and consists of $76 \%$ with securities for sale, $9 \%$ - maturity and $15 \%$ - in the trading portfolio. The most rapid growth, in absolute terms, at the end of 2018 was shown by securities in the portfolio of banks for sale, which at the end of 2018 amounted to almost UAH $87 \mathrm{~B}$. Analyzing the structure of the investment portfolio of Ukrainian banks, it is necessary to focus on the current requirements for reflecting investments in securities in the financial statements of banks. Such requirements are established by the Instruction on accounting of transactions with securities in banks of Ukraine, approved by the resolution of the Board of the National Bank of Ukraine No. 358 of 03.10.2005. According to it, there are types of Bank investments in securities [4]: 1) securities accounted for in the trading portfolio; 2) securities in the bank's portfolio for sale; 3) securities in the bank's portfolio for repayment; 4) investments in associates and subsidiaries. According to the above classification, we will analyze the structure of Ukrainian banks' investments in securities, using the data from Table 2.8. 
Dynamics of bank securities, UAH mln.

\begin{tabular}{|c|c|c|c|c|c|}
\hline \multirow{2}{*}{ Indicator } & \multicolumn{5}{|c|}{ Research years } \\
\cline { 2 - 6 } & $\mathbf{2 0 1 4}$ & $\mathbf{2 0 1 5}$ & $\mathbf{2 0 1 6}$ & $\mathbf{2 0 1 7}$ & $\mathbf{2 0 1 7}$ \\
\hline I. Securities other than shares & 78494 & 91376 & 130418 & 144574 & 110761 \\
\hline I.1. By sectors of the economy & & & & & \\
sector of other financial institutions & 1579 & 1859 & 3062 & 5564 & 2502 \\
general government sector & 60701 & 66737 & 93952 & 109915 & 89293 \\
non-financial corporations sector & 13645 & 20258 & 30720 & 27551 & 17778 \\
others (sectors of the economy, deposit- & & & & & \\
taking corporations, non-residents) & 2569 & 2522 & 2684 & 1544 & 1188 \\
\hline I.2. By portfolio type: & & & & & \\
in the trading portfolio & 9756 & 15605 & 9197 & 22105 & 17320 \\
in the portfolio for sale & 58290 & 71113 & 116740 & 118694 & 84008 \\
in the portfolio to maturity & 10448 & 4658 & 4481 & 3775 & 9433 \\
investments in associates and subsidiaries & 0,0 & 0,0 & 0,0 & 0,0 & 0,0 \\
\hline II. Shares in the portfolio of banks & 5984 & 6948 & 7411 & 7241 & 3851 \\
\hline II.1. By sectors of the economy: & & & & & \\
banking sector & 9 & 9 & 330 & 331 & 35 \\
sector of other financial corporations & 2647 & 2717 & 2213 & 1404 & 651 \\
sector of non-financial companies & 2042 & 2420 & 2930 & 2504 & 938 \\
non-residents & 1286 & 1802 & 1938 & 3002 & 2227 \\
\hline II.2. By portfolio type: & & & & & \\
in the trading portfolio & 1737 & 1643 & 1893 & 1180 & 96 \\
in the portfolio for sale & 2315 & 2985 & 2752 & 2842 & 2679 \\
in the portfolio to maturity & 0,0 & 0,0 & 0,0 & 0,0 & 0,0 \\
investments in associates and subsidiaries & 1932 & 2320 & 2766 & 3219 & 1076 \\
\hline
\end{tabular}

Source: calculated by the authors according to [11; 14; 21].

During the period 2013-01.10.2016, all components of the portfolio of financial investments of the Ukrainian banking sector grew. Thus, during the analyzed period, the largest share in the securities portfolio is held by securities for sale $-73.4 \%$ in 2013 and $85.0 \%$ in 2017 .

Trading operations are significantly more prevalent than investment operations $-(86.8 \%$ of trading operations, $13.2 \%$ of investment operations in 2013 to $85 \%$ and $15 \%$ respectively in 2017).

During the analyzed period, there were no significant changes in the structure of the securities portfolio, trading operations continue to play a leading role, but the share of securities held to maturity has significantly increased. The structure of the portfolio for sale is dominated mainly by debt securities and accounted 
Table 2.8

\section{Dynamics of structural changes in the securities portfolio of Ukrainian banks, UAH mln.}

\begin{tabular}{|c|c|c|c|c|c|c|}
\hline \multirow{2}{*}{ Indicator } & \multicolumn{6}{|c|}{ Researched period } \\
\hline & 2013 & 2014 & 2015 & 2016 & 2017 & 01.10 .2018 \\
\hline $\begin{array}{l}\text { Securities in the } \\
\text { Bank's portfolio } \\
\text { share }\end{array}$ & $\begin{array}{c}87182.8 \\
100.0\end{array}$ & $\begin{array}{c}93928.4 \\
100.0\end{array}$ & $\begin{array}{c}135593.1 \\
100.0\end{array}$ & $\begin{array}{c}160554.0 \\
100.0\end{array}$ & $\begin{array}{c}156661.8 \\
100.0\end{array}$ & $\begin{array}{c}159339.6 \\
100.0\end{array}$ \\
\hline $\begin{array}{l}\text { In the trading } \\
\text { portfolio } \\
\text { share }\end{array}$ & $\begin{array}{c}11687.5 \\
13.4\end{array}$ & $\begin{array}{c}17462.6 \\
18.6\end{array}$ & $\begin{array}{c}9828.9 \\
7.2\end{array}$ & $\begin{array}{c}20285.8 \\
12.6\end{array}$ & $\begin{array}{c}\text { not } \\
\text { available } \\
\text { not } \\
\text { available }\end{array}$ & $\begin{array}{c}\text { not } \\
\text { available } \\
\text { not } \\
\text { available }\end{array}$ \\
\hline $\begin{array}{c}\text { In the portfolio for } \\
\text { sale } \\
\text { share }\end{array}$ & $\begin{array}{c}63990.3 \\
73.4\end{array}$ & $\begin{array}{c}70597.8 \\
75.2 \\
\end{array}$ & $\begin{array}{c}119003.7 \\
87.8\end{array}$ & $\begin{array}{c}132099.1 \\
82.3\end{array}$ & $\begin{array}{c}133033.7 \\
85.0\end{array}$ & $\begin{array}{c}139026.4 \\
87.2\end{array}$ \\
\hline $\begin{array}{l}\text { In the portfolio for } \\
\text { re-payment } \\
\text { share }\end{array}$ & $\begin{array}{c}9573.3 \\
11.0\end{array}$ & $\begin{array}{c}3547.7 \\
3.8\end{array}$ & $\begin{array}{c}3995.1 \\
3.0\end{array}$ & $\begin{array}{c}6099.4 \\
3.8\end{array}$ & $\begin{array}{c}22552.2 \\
14.4\end{array}$ & $\begin{array}{c}19425.0 \\
12.2\end{array}$ \\
\hline $\begin{array}{l}\text { Investments in } \\
\text { associates and } \\
\text { subsidiaries } \\
\text { share }\end{array}$ & $\begin{array}{c}1931.7 \\
2.2\end{array}$ & $\begin{array}{c}2320.3 \\
2.4\end{array}$ & $\begin{array}{c}2765.4 \\
2.0\end{array}$ & $\begin{array}{c}2069.7 \\
1.3\end{array}$ & $\begin{array}{c}1075.9 \\
0.6\end{array}$ & $\begin{array}{c}888.2 \\
0.6\end{array}$ \\
\hline
\end{tabular}

Source: calculated by the authors according to [11; 20-21; 43]

for 73.4 and $85.0 \%$ respectively in 2013 and 2017 . The portfolio consists exclusively of debt securities (as stipulated by the regulatory legislation). During that period, the portfolio of securities of this type has grown, and as of 01.01.2018 amounted to UAH 22.5 B. As for bank investments in shares and other non-trading securities, during 2013-2017, they decreased by $31.51 \%$ and amount to about UAH $2.8 \mathrm{~B}$. The above data indicate both a low interest of banks in buying shares of enterprises and an insufficient number of investmentattractive shares in the free sale on the stock market.

Investments in associated companies traditionally have a small share in the se-curities portfolio of the Ukrainian banks. At the beginning of 2018 , it amounted only $0.6 \%$, i.e. the creation of subsidiaries, particularly in the financial sector, is not a priority for banks at the current stage of development of the national banking sector. However, we cannot exclude the possibility of further indirect participation of banks in the functioning of such structures by making indirect (hidden) investments. 
Among financial instruments for trading volume in the stock market the lead-ing position is taken by government bonds, stocks and corporate bonds, indicating greater activity of the state in the borrowing through the issuance of financial instru-ments, but even under these conditions, most transactions among banks was carried out by three banks that do not declare themselves as an investment, and have the character of savings and/or universal bank, and namely [11; 21-24; 26] JSC "Ukreximbank", JSC "VTB Bank" and JSC "Ukrsotsbank". The PJSC CB "PrivatBank" focuses (and in some periods exclusively) on trading government bonds on the exchange (OTC) market and corporate bonds on the OTC market, respectively, occupying leading positions (Figure 2.5-2.6).

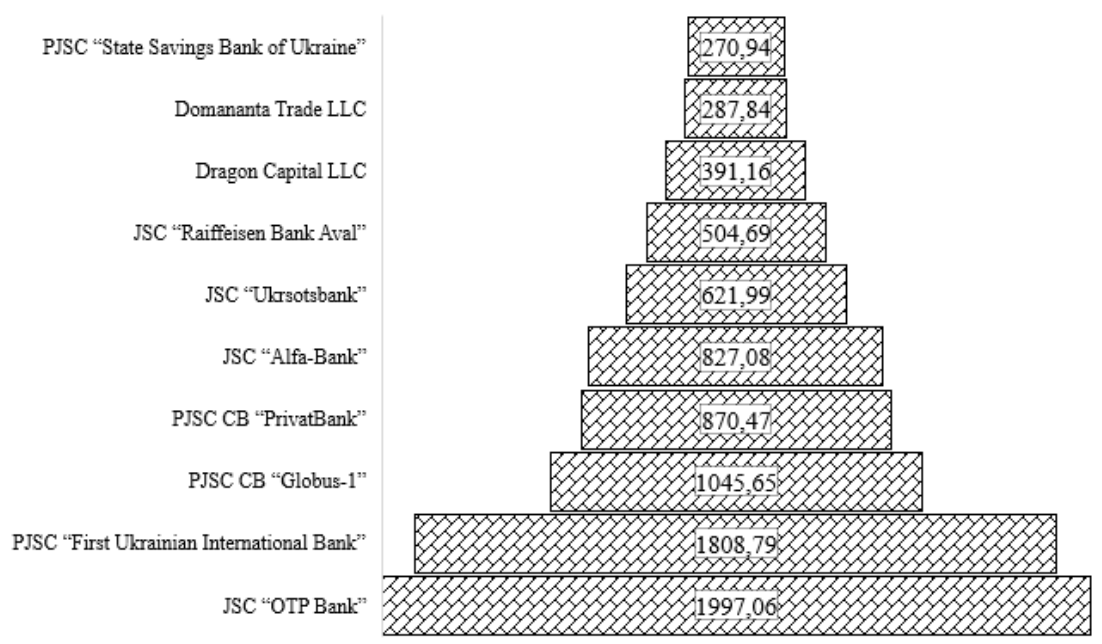

\section{Figure 2.5. Place of the PJSC CB "PrivatBank" among the largest traders of govern-ment bonds on the OTC market (excluding the primary market) in 2018, UAH mln.}

Source: calculated by the authors according to [20-21;24;26]

Peter Krumhansl, Chairman of the Board, PJSC CB "PrivatBank", stated that "approximately $20 \%$ of the profit of the state-owned PrivatBank is generated by in-come from domestic government bonds which were used to recapitalize the bank after its nationalization in 2016" [24]. 


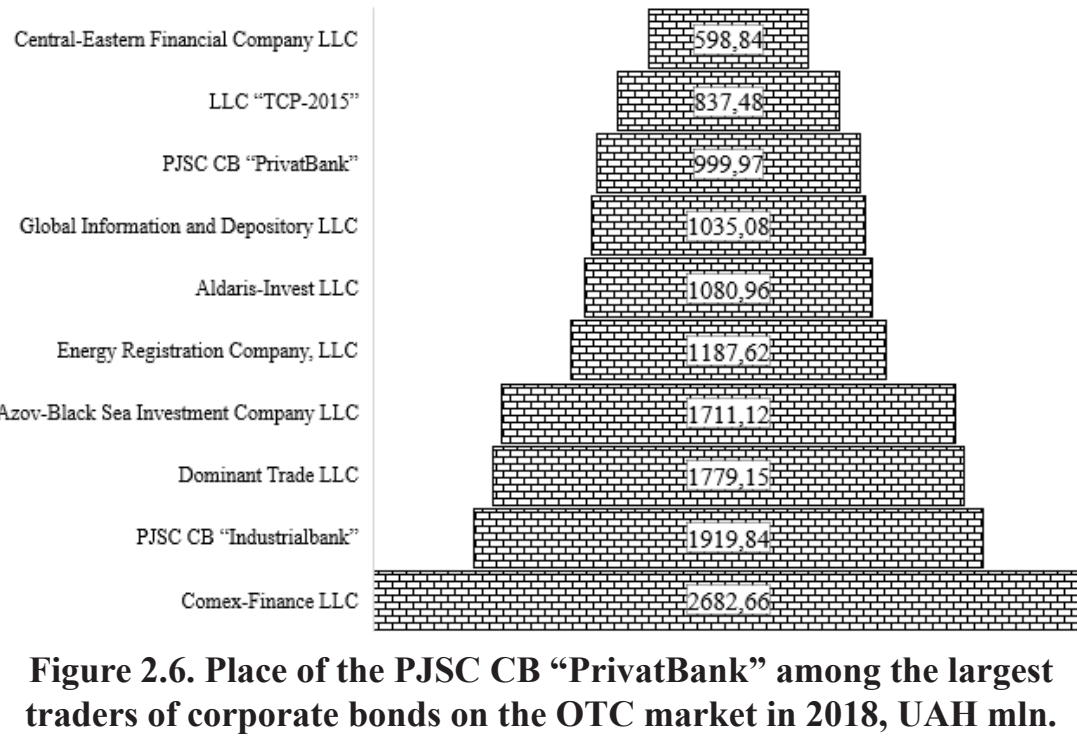

Source: calculated by the authors according to [20-21; 24; 26$]$

This explains the penetration of domestic government bonds in the mobile application Privat 24 - on the one hand, it has allowed both legal entities and individuals to buy them, and on the other - to ensure the development of institutional mechanisms for the security of its activities on the stock market with the priorities of the Ministry of Finance of Ukraine as the owner of the bank and of the functioning of the national stock market, its parity trends in the development of the banking sector of Ukraine. There are several reasons for the low investment activity of Ukrainian commercial banks in general and the PJSC CB "PrivatBank" in particular - most of them are due to the imperfection of the securities market and significant regulatory influence on the market by the state. As a result, insignificant volumes of transactions with securities versus credit ones and low liquidity of this segment of the financial market, where most securities do not have regular quotations; the inability to generate an adequate array of statistical data necessary to obtain reliable results using statistical analysis methods; the lack of reliable investment ratings of internal issuers of securities. 


\section{Taxonomic approach to the assessment of security provision for activities of the PrivatBank in the exchange market as a leading state provider of goal settings for the concept of "green" modern of the national economy}

In the published strategy of the PJSC CB "PrivatBank" until 2022 [24] among the bank's transformations, there is no mention of its further integration with the stock market, in particular in terms of developing the existing potential for selling domestic government bonds rather, on the contrary, it is proposed (an approach called "ensuring a reasonable compromise between financial attractiveness and reliability") to gradually reduce the scale of its activities on the stock market in order to optimize the state's expenditures for its exit from the bank's capital. As a consequence, a well-established methodological approaches to the determination of the level of financial security of commercial banks (economic-mathematical methods, methods, which are based on the calculation of indicators reflecting the level of bank financial security, regulations (calculation of economic standards of banking activity proposed by the regulator), methods based on assessing the risks of banking activities as a key performance indicator ensure the financial security of bank and expert methods) are not representative relative to the assessment of the level of security of the bank's activity in the stock market due to the lack of relevant diagnosis of problems of numerous bankruptcies of Ukrainian banks including through their ineffective activities on the stock market, has necessitated the assessment of the level of bank financial security on the basis of comparison indicators of incentives (disincentives) security activities of the PJSC CB "PrivatBank" in the stock market with a reference "bankrupt bank" with the subsequent determination of the mathematical distance of the indicators of financial security of PJSC CB "PrivatBank" in the stock market against the performance indicators of the "bankrupt bank". Schematics for assessing the level of security of the PJSC CB "PrivatBank" in the stock market are presented in Figure 3.1 and Figure 3.2.

So, a lot of performance factors of the PJSC CB "PrivatBank" contains two groups of indicators proposed in Figure 3.1: first, indicators for rating financial security of the bank and the security of its activities on the stock market in particular on the basis of the diagnosis of the profitability and structure of assets and liabilities (when the selected indicators are incentives, the standardization should be recom-mended (normative) in 


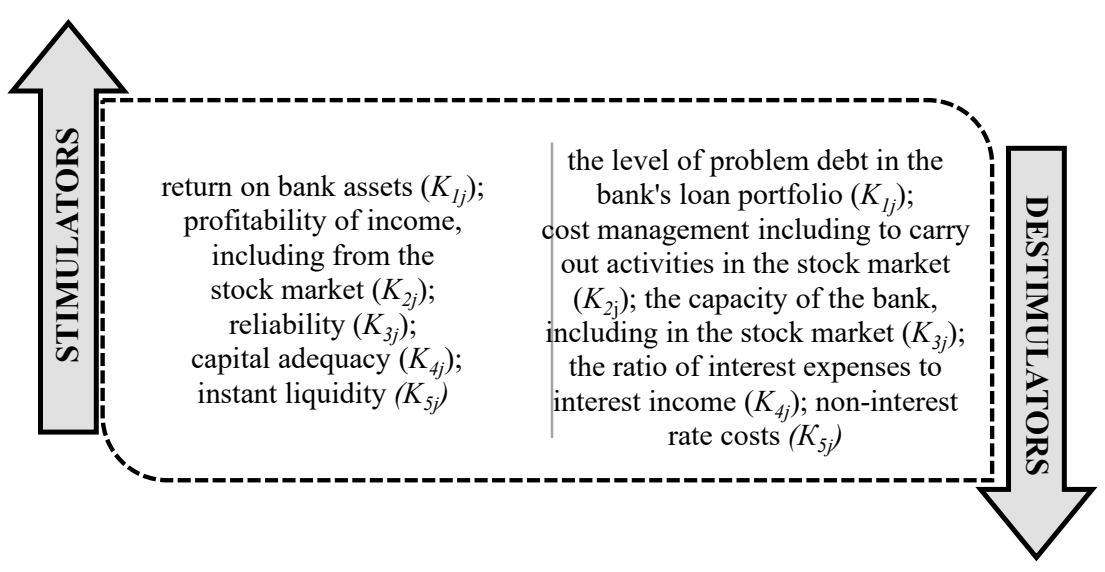

Figure 3.1. A set of incentive and disincentive indicators for assessing the security of the Bank's activities in the stock market

Source: grouped by authors $[15 ; 17 ; 30 ; 48]$

[11; 51] relations); second, the indicators for the rating as-sessment of PJSC CB "PrivatBank" on the basis of indicators of income and expenses (that is, when the selected indicators are disincentives, the standardization should be recommended (normative) in $[11 ; 47]$ relationships).

At the first stage of assessing the level of security of the Bank's activities in the stock market, the characteristics of a certain reference Bank-bankrupt are calculated, that is, the average performance indicators of the bank that is recognized by the National Bank of Ukraine [11] as insolvent, was liquidated and received a rating below the average for the results of the annual evaluation of the National Securities and Stock Market Commission [21]. Financial reporting data of banks including the PJSC CB "PrivatBank" assets, liabilities, capital and financial results are obtained either from the official websites of the respective banks [22-24] or the website of the National Bank of Ukraine [11]. Based on these statistics, we calculated stimulating and/or discouraging indicators, that is, performance indices of banks, including the PJSC CB "PrivatBank", that characterize various aspects of their activities from the point of view of ensuring financial security in General and the security of its activities on the stock market in particular. 
1. Formation of a set of absolute indicators of the bank's activity, which can be obtained from the public financial statements posted on the official website or generalized information of the NBU on the functioning of the banking sector
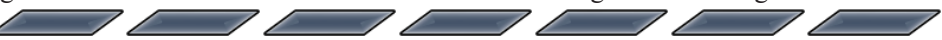

2. Calculation of relative performance indices of the bank on the basis of the set of indicators formed in the first step, which characterize various aspects of its activities, including the stock market

3. Construction of a conditional "reference" bank (a bank that, according to the researcher, has the best (worst) relative characteristics of financial security, including activities in the stock market), with which we will compare the level of financial security of JSC CB "PrivatBank"*

4. Determining the integral value of the level of security of the bank in the stock market (determined by the degree of proximity to the reference bank) and its interpretation

5. Study of the dynamics of the level of security of the bank's activities in the stock market and identification of key incentive (disincentive) factors

6. Interpretation of the obtained results of security of the bank's activity on the stock market

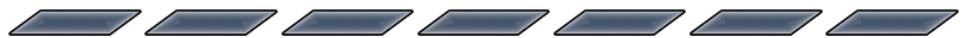

Legend:

"** - the calculation of the integral value of the level of financial security of the reference bank is performed using the method of reduction. The choice of the reference bank can be made in different ways, in particular, as a «reference bank» it is advisable to take a bank with average group characteristics; a bank with average characteristics in the banking sector; bank with reference values of indicators. In our case, the «benchmark bank» was taken with the average values of performance indicators of banks that received significant losses from the stock market.

\section{Figure 3.2. Schematics of assessing the level of security of PJSC CB "PrivatBank" in the stock market}

Source: modified by the authors based on [43]

After forming a set of indicators under study, we perform their statistical pro-cessing and determine the average characteristics of the reference bankrupt bank. Statistical processing of the input set of indicators of the bank security performance in the stock market is due to the fact that the relative characteristics of the bank's performance in general and in the stock market may differ significantly depending on its specifics, size, and specialization. In particular, for state-owned banks, which is the PJSC CB "PrivatBank" 
(with one hundred percent state ownership), there is a significant variation in the values of the studied indicators.

For statistical processing of the input data, the method of their reduction (clearing) is used by calculating the interquartile range (IQR), which allows to identify and exclude atypical data ("outliers"), that is, values that are at a distance that is less than 1.5 IQR from the first quartile Q1 or more than 1.5 IQR from the third quartile Q3. Therefore, to determine the level of bank security in the stock market, we will use only the value of the stimulation (Table 3.1) or destimulation (Table 3.2) indicators, that lie in the plane of the corresponding indicator. Let's assume that [25]: first quartile Q1 - is the value of an ordered data series that divides the series into two parts: the first contains $25 \%$ of the values (observations), and the other contains $75 \%$; quartile Q3 is a number that divides the series into parts with 75 and $25 \%$ of the values, and IQR is the difference between the third and first quartiles.

Table 3.1

The calculated value of stimulation indicators of a conditional
reference bankrupt bank (including on the stock market)

\begin{tabular}{|c|c|c|c|c|c|}
\hline $\begin{array}{c}\text { Quarters before bankruptcy and } \\
\text { publication of the annual report } \\
\text { of the National Securities and } \\
\text { Stock Market Commission }\end{array}$ & \multicolumn{5}{|c|}{$\begin{array}{c}\text { The legend of destimulation indicators } \\
\text { (as shown in Figure 3.1) }\end{array}$} \\
\cline { 2 - 7 } & $\boldsymbol{K}_{\mathbf{1 j}}$ & $\boldsymbol{K}_{\mathbf{2 j}}$ & $\boldsymbol{K}_{\mathbf{3 j}}$ & $\boldsymbol{K}_{\mathbf{4 j}}$ & $\boldsymbol{K}_{\mathbf{5} \boldsymbol{j}}$ \\
\hline IV & 0.0015 & 0.0301 & 1.1397 & 0.2381 & 0.5850 \\
\hline III & 0.0011 & 0.0154 & 2.0103 & 0.2333 & 0.7118 \\
\hline II & 0.0009 & 0.0099 & 5.0541 & 0.2414 & 0.5870 \\
\hline I & 0.0003 & 0.0047 & 3.3240 & 0.2365 & 0.5008 \\
\hline
\end{tabular}

Source: calculated by the authors according to [11;26]

Based on table 3.1, it can be concluded that as the date of declaring bankruptcy of a commercial bank and the publication of the annual report of the National Commission on Securities and Stock Market [21] concerning the activities of banks in the stock market approached, its profitability significantly decreased, in particular, over the last four quarters before the publication of statistical information, its revenue profitability decreased more than fourfold from $0.1557 \%$ in the fourth quarter to $0.0371 \%$ in the quarter before its publication. 
Table 3.2

\section{The estimated value of the destimulating indicators of conditional reference bankrupt bank (including at the stock market)}

\begin{tabular}{|c|c|c|c|c|c|}
\hline \multirow{2}{*}{$\begin{array}{c}\text { Quarters before bankruptcy } \\
\text { and publication of the annual } \\
\text { report of the National Securities } \\
\text { and Stock Market Commission }\end{array}$} & \multicolumn{5}{|c|}{$\begin{array}{c}\text { Symbols of the stimulating indicators (as } \\
\text { shown in Figure 3.1) }\end{array}$} \\
\cline { 2 - 7 } & $\boldsymbol{K}_{\mathbf{1} \boldsymbol{j}}$ & $\boldsymbol{K}_{\mathbf{2}}$ & $\boldsymbol{K}_{\mathbf{3 j}}$ & $\boldsymbol{K}_{4 \boldsymbol{j}}$ & $\boldsymbol{K}_{\mathbf{5} \boldsymbol{j}}$ \\
\hline IV & 4.2733 & 0.3942 & 0.7895 & 0.6464 & 0.0337 \\
\hline III & 3.9128 & 0.4051 & 0.9352 & 0.6348 & 0.0287 \\
\hline II & 2.9621 & 0.3655 & 0.8150 & 0.6257 & 0.0341 \\
\hline I & 1.2241 & 0.4391 & 0.8180 & 0.6328 & 0.0301 \\
\hline
\end{tabular}

Source: calculated by the authors according to [11;26]

At the same time, the return on income of the conditional reference bankrupt bank for the year before bankruptcy and three quarters before the release of statistical information of the National Securities and Stock Market Commission decreased by more than six times from $3.0111 \%$ in the fourth quarter before bankruptcy to $0.4717 \%$ in the quarter before the release of statistical information.

The dynamics of other incentive indicators is not unambiguous, in particular, the value of the reliability indicator increases, which can be explained by a decrease in the amount of funds raised by the Bank, but in the last quarter before the bankruptcy and the publication of relevant statistical information, its value decreases, which may be due to the withdrawal of the bank's own capital, discontinuation of the activities on the stock market. The instant liquidity indicator tends to decrease in the last quarters before the bank is declared insolvent, its bankruptcy and the publication of relevant statistical information by the National Securities and Stock Market Commission, in particular, three quarters before the value of this indicator is equal to 0.7118 p.p. and decreases to 0.5008 in one quarter.

Monitoring of the effective values of destimulation indicators of the bank's security in the stock market (Table 3.2) showed that the share of overdue loans in their loan portfolio decreased from $4.2733 \%$ four quarters before the bankruptcy and the publication of relevant statistical information by the National Securities and Stock Market Commission to $1.2241 \%$ one quarter before the corresponding process. This trend can be explained by the introduction of various mechanisms for restructuring overdue loans, 
transferring them to other categories, and the concentration of the bank's activities on the stock market on highly liquid securities. The indicator of the bank's business capacity and interest expenses in interest income in general tend to decrease, which may be due to optimization (reduction) of the bank's expenses on the stock market.

To determine the level of security of the Bank's activities on the stock market, it is necessary to calculate the measure of proximity (distance) between the indicators of the PJSC CB "PrivatBank" and conditional reference bank. For this purpose, in the scientific literature [51], various metrics are used as a measure of proximity between two objects, in particular, Euclidean distance (simple and weighted), generalized degree distance (Minkowskian distance), linear (Manhattan) distance, and so on. However, in our opinion, it is advisable to use a simple Euclidean measure of distance to calculate the distance between the PJSC CB "PrivatBank" and a conditional reference rank. Since an average problem bank with low efficiency rates in the stock market is selected as the reference bank, the incentive factors will be calculated as the distance for the values not exceeding the value of the reference bank and for destimulating - on the contrary, those that are lesser than those of the reference bank. For this purpose, we will introduce indicators $a_{j}$ for each $j$-th security factor of the bank's activity in the stock market, which takes the value of one if the incentive factor of the PJSC CB "PrivatBank" exceeds the reference value or the disincentive factor is less than the reference value, i.e. it describes a favorable level of security of the bank's activities in the stock market. At the same time, due to the adverse influence of the studied factors (the value of the incentive factor of the PJSC CB "PrivatBank" is less than the reference one or the disincentive factor exceeds the reference one), the $a_{j}$ indicator takes zero value. Then the distance between the level of security of the PJSC CB "PrivatBank" on the stock market and the conditional reference bank, that is, the degree of approximation of the level of total (integral) financial security of PJSC CB "PrivatBank" to the state of a crisis bank with low quantitative and qualitative characteristics of activities on the stock market will be calculated using the schematics shown in Figure 3.3.

When determining the level of security of the Bank's activities on the stock market, we assume that if the value of the incentive factor of the PJSC CB "Privat-Bank" is greater than the corresponding value of 
the conditional reference Bank or lower for the disincentive factor, this indicates a sufficient level of financial security of its activities on the stock market and there is no real threat of bankruptcy. In the opposite case, when the value of incentive factors is less than the reference or the value of disincentive factors is greater than the reference - this indicates a high level of risk of loss of financial security of the bank's activities on the stock market, which, if adequate anti-crisis measures are not applied, may lead to a reduction in the scale of its activities on the stock market, or even to the formation of a stable level of risks of further bankruptcy. The analysis in Figures 3.4-3.5 showed that the most critical situation in the joint-stock company "Misto Bank", as evidenced by the smallest distance value from the reference bank, i.e. the values of the factors of financial security and performance of the stock market is significantly lower for the reference, and therefore, the security level of the bank's activity in the stock market need to recognize unsatisfactory, that is catastrophic.

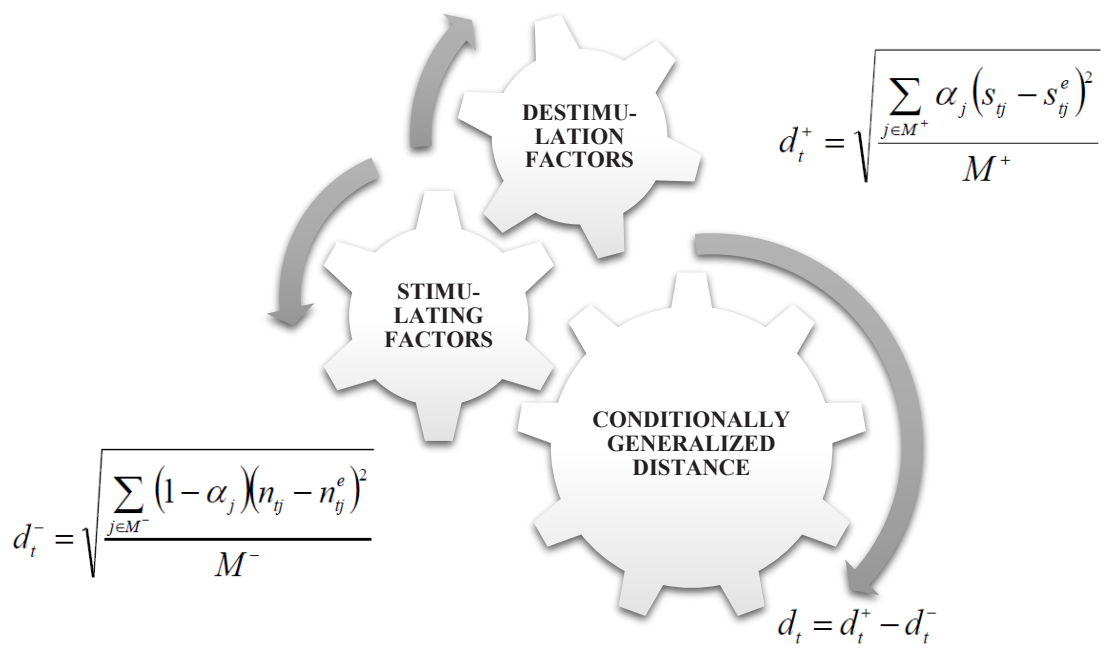

Figure 3.3. Schematics for calculating the distance between the security level of a bank's activity on the PJSC CB "PrivatBank" stock market and a conditional reference bank

Source: compiled by the authors [35; 44] 
Also, the unsatisfactory level of security of the Bank's activities on the stock market is inherent in the PJSC CB "PrivatBank" but its nationalization and recapitalization by the state in the amount of UAH 148 B [11; 14; 24] saved it from bankruptcy, and the strategic focus on the stock market exclusively on domestic government bonds provided a relative mediocrity of safety indicators and performance of its activities in this market. The jointstock company "Ukrsotsbank" is also characterized by an unsatisfactory level of security in the stock market.

Security of activities of a number of Ukrainian banks on the stock market in-cluding the JSC "Ukreximbank", JSC "Sberbank", joint-stock bank "Ukrgasbank", JSC "Raiffeisen Bank Aval”, JSC "UkrSibbank", public joint-stock company "Bank Credit Dnipro" and PJSC "Tascombank", can be described as acceptable but they are at risk and require constant monitoring of security activities in the stock market and for the public jointstock company "ING Bank Ukraine" and JSC "Misto Bank" level security activity in the stock market should be regarded as relatively reliable, their security is much better than those of the conditional reference bank.

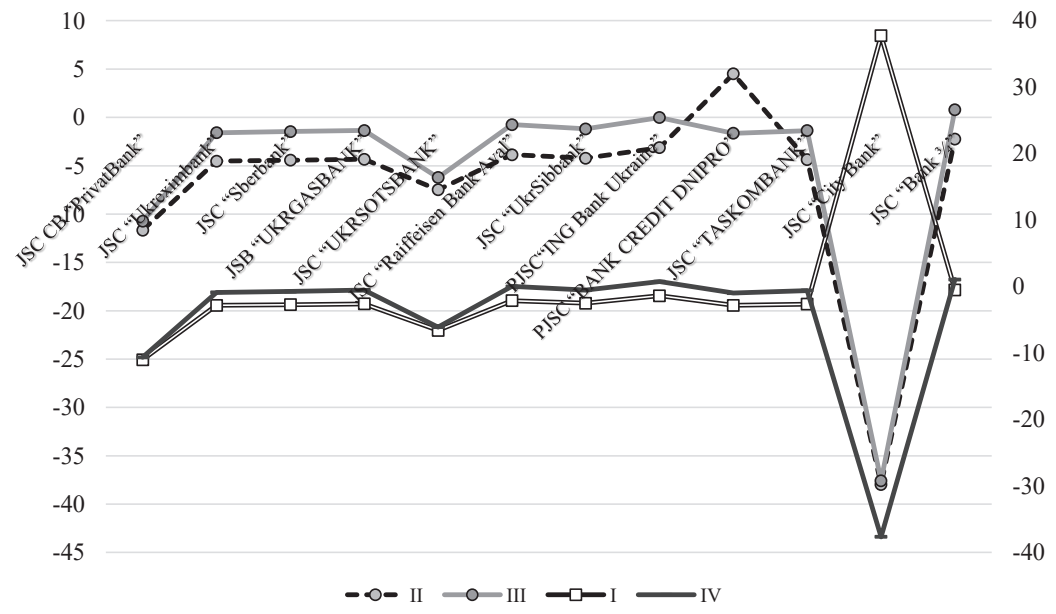

Figure 3.4. Visualization of the conditional general distance of the level of financial security of the PJSC CB "PrivatBank" in the stock market from the reference bank in 2018

Source: compiled by the authors [11;24; 26; 38$]$ 
Today, the key risk to the financial security of the PJSC CB "PrivatBank" is the unfavorable external environment of Its activities, including in the stock market, due to the adoption in April-May 2019 of a number of court decisions that cast doubt on the legitimacy and expediency of PJSC CB "PrivatBank" nationalization in December 2016. These decisions are now in the appeal status.

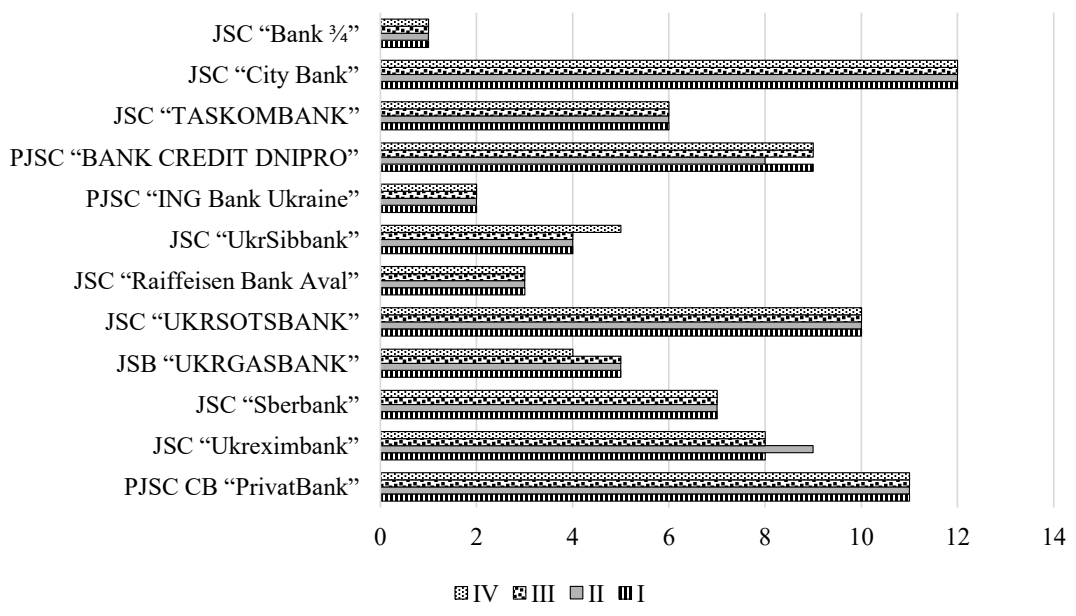

\section{Figure 3.5. Ranking of the conditional general distance of the level of financial security of the PJSC CB "PrivatBank" on the stock market from the reference bank in 2018}

Source: compiled by the authors [11; 24; 26; 38$]$

However, according to $[11 ; 14 ; 24]$, from the beginning of 2019 , the PJSC CB "PrivatBank" became profitable even without taking into account the generated income from activities on the stock market, primarily embodied in the purchase (sale) of domestic government loan bonds, but in JSC "Oschadbank" and JSC "Ukreximbank", these revenues are generated through lending to individuals and/or legal entities. In the future, the share of coupon payments on domestic government bonds in the interest income of state banks in general and PJSC CB "PrivatBank", in particular, will steadily decrease due to the gradual repayment of government securities from their portfolio, significantly reducing and destimulating the scaling of 
activities on the stock market, the concentration of specialized services on ensuring its security.

A significant risk to the security of the PJSC CB "PrivatBank" is the transfor-mation of the client base of the government securities. Thus, in March, Clearstream and the National Bank of Ukraine signed an agreement to open an international de-pository account with the National Bank of Ukraine's Depository, meaning that the national stock market joined the international one on May 27, 2019. Simplification of access of foreign investors to state securities will entail an institutional transformation of the state securities market in the direction of banks with foreign capital, and accordingly, the existing strategy for ensuring the security of the activities of the PJSC CB "PrivatBank" in the stock market requires a corresponding correction.

\section{Conclusions}

One of the methodological problems that centers around security of the bank activity in the stock market as a whole and at the level of PJSC CB "PrivatBank" is the lack of special legal acts on banking security, the definition of "financial security of bank operations" and "security of the bank activity in the stock market", regula-tion, the order of the Ministry of Finance of Ukraine No. 316 "On Decision of the shareholder of the PJSC CB "PrivatBank" of February 23, 2018 requirements for specification of existing and potential safety risks of its activities on the stock market in particular in the application of the special security service of PJSC CB "Privat-Bank". This creates institutional uncertainty, inerting the conflict of laws rules of the applicable law in the relevant rules and regulations of the banking sector in general and the PJSC CB "PrivatBank" in particular, creating a terminological discrepancy between endo - and exostatistical sources of PJSC CB "PrivatBank", except for evaluating the safety of its activities on the stock market.

Accordingly, in the Financial Stability Report approved by the Financial Sta-bility Committee of the National Bank of Ukraine on December 13, 2019, the applied indicators fully characterize the entire range of banking operations, including those that occur on the stock market, without allowing to assess the level of threats associated with them. These indicators mainly describe quantitative and qualitative parameters of assets, capital, attracted 
and invested funds, and do not allow us to assess in detail either the quality of the balance sheet of the banking sector, or the role of individual banks in the formation and development of the national stock market. This leads to contradictory estimates, since, in conditions of high volatility and cyclical development of the banking sector, indicators that characterize various aspects of its functioning are different, and there is not always a direct link between the resulting financial and other indicators of banking activity and its regulation and supervision. This renders it impossible to make an unambiguous assessment of the level of security of the bank's activities in the stock market, and thus to make informed management decisions.

The level of financial stability of the banking sector remains quite low since the vast majority of institutional banking links do not fit into the recommended (threshold) values of indicators in the context of resourcecreating, deposit, credit, currency, debt, investment security and the safe level of income and expenses, in particular, generated from the bank activities on the stock market. Accordingly, JSC "Misto Bank" experiences the most critical situation regarding the level of bank security on the stock market as evidenced by the lowest value of the conditional distances from the reference bank, i.e. the values of the factors of financial security and performance of the stock market is significantly lower than the reference ones, and therefore, the security level of the bank activity in the stock market should be recognized unsatisfactory, that is catastrophic. Also, the unsatisfactory level of security of bank activities on the stock market is inherent in the PJSC CB "PrivatBank" however its nationalization and recapitalization by the state in the amount of UAH 148 B saved the institution from bankruptcy, and its strategic focus on the stock market exclusively on domestic government bonds ensured that its safety and performance indicators in this market were relatively mediocre. However, the key drawbacks of the security system of the PJSC CB "PrivatBank" in the stock market are:

firstly, the lack of an effective mechanism for assessing the financial interests of the bank, its clients and the state represented by the Ministry of Finance of Ukraine to fully assess multisectoral risks, including those that arise in other financial and economic spheres, causing an increase in crisis phenomena and shocks in the activities of PJSC CB "PrivatBank";

secondly, the unfavorable external environment of PrivatBank's activities, in-cluding in the stock market, as a result of the adoption in 
April-May 2019 of a number of court decisions that question the legality and expediency of its nationalization;

thirdly, non-compliance of the 2022 Strategy of the PJSC CB "PrivatBank" with the expected transformation of the client base of government securities including domestic government bonds and reducing the proportion of the coupon payment on domestic government bond interest income of PJSC CB "PrivatBank", which steadily decrease due to the gradual repayment of government securities from its portfolio, significantly reducing and destimulating upscale of activities of PJSC CB "PrivatBank" in the stock market, the concentration of specialized services to ensure its safety.

A lack of synchronicity of the regulation of the European Green Deal, Green Deal of Ukraine and a methodological basis of financial stability, in general, and a macroprudential policy, in particular, has also caused information asymmetry in as-sessing the banking system potential in providing normative regulations in the "greening" of sectors of the national economy. A backbone state bank - PJSC CB "PrivatBank" - has not become an exception. So, granting loans to small and medium business in 2019 to the total amount of UAH $5.4 \mathrm{~B}$, against the background of the chosen "Balance and Caution" financial strategy, has created formal barriers to potential recipients to obtain funds for the "greening" of their activities and concurrently has made impossible to form a relevant empiric basis. However, within the framework of the current national model of the Green Deal of Ukraine - "warm" loans - PJSC CB "PrivatBank" financed 1,106 apartment building co-owner associations (approximately, $12 \%$ of those having active accounts with banks) in the amount of UAH $410 \mathrm{M}$ (on average, UAH $370.7 \mathrm{~K}$ per association). However, from the state and local budgets, just UAH 118 and 39 M respectively, were refunded, that is $38.29 \%$ of granted money supply of "warm" loans. It is clear that the said program does not allow to objectively assess the ability of the banking system, in general, and PJSC CB "PrivatBank", in particular, to finance the Green Deal of Ukraine projects, however, allows to state that:

existing normative regulations and strategic programs in Ukraine are limited to just establishing a Governmental Inter-Agency Group on Coordination of Overcom-ing the Consequences of Climate Change within the Framework of the European Green Deal headed by the Ukraine's VicePrime Minister for European and Euro-Atlantic Integration as well as to a 
letter to First Vice President of the European Commission F. Timmermans of Ukraine's intent of modalities of early involvement in developing and implementing policies within the framework of the European Green Deal, developing a joint roadmap;

a key element of most world programs of the New Green Deal is to provide a transition to carbon neutrality at the equator of the century. In this context, the Ministry of Energy and Environmental Protection of Ukraine presented, at the beginning of 2020, a draft Concept of "Green" Energy Transition of Ukraine until 2050. In its framework, the following priorities are determined: de-carbonization (in all its manifestations) of the economy, in general, and the energy system, in particular; low-carbon and resource-efficient industry; ecologically clean transport. Implementing said directions will take place using financial instruments tested within the framework of "warm" loan programs carrying new opportunities for the PrivatBank's participation in the "greening" of the national economy including that by crediting projects of complex thermo-modernization of both multi-apartment and individual houses;

as a result of implementing the Green Deal, the economy of Ukraine will dras-tically change, new sectors, new industries will appear within the framework of the traditional rural economy and environmental economy while a link between the eco-nomic growth, on the one hand, and resource consumption, environmental contamination, greenhouse gas emissions, on the other hand, will be broken. In this context, in order to maintain own leading positions in the segment of the regulatory providing and financing of modernization of small and medium business in the direction of its "greening", the PJSC CB "PrivatBank" needs to immediately actualize the provisions of its strategy until 2022, subject to new market segmentation, prioritization of recipients of loans, their channeling, first of all, for the needs of the "green" modern.

However, taken into account the need to form the common mental space for channels, sources, mechanisms of financial support of the Green Deal of Ukraine within the framework of the European Green Deal, prospective research intelligences are the matters associated with deepening empiric research of a degree of involvement of financial-and-credit institutions in the "greening" of sectors of the national economy, participation in said processes by backbone state banks as providers (stakeholders) of relevant 
budgetary programs and concurrently "green" donors of development of small and medium business in rural areas, energy industry, construction etc.

\section{References:}

1. Azarenkova G. M., Shkodina I. V. (2012) Osnovni tendenciji rozvytku fondovogho rynku v postkryzovyj period [The main trends in the stock market in the post-crisis period]. Visnyk NBU, no. 2, pp. 3-7. (in Ukrainian)

2. Aljejnikova N. M. (2016) Funkcionuvannja fondovogho rynku Ukrajiny $\mathrm{v}$ umovakh ekonomichnoji nestabiljnosti finansovogho seredovyshha [The main trends in the stock market in the post-crisis period]. Visnyk ONU imeni I. I. Mechnikova, vol. 21, iss. 4(46), pp. 144-149. (in Ukrainian)

3. Kyrychenko O. A., Mischenko V. I. (2005) Bankivsjkyj menedzhment [Banking management]. Kyiv: Znannja. (in Ukrainian)

4. Baranovskyi O. I. (2014) Filosofiia bezpeky [Philosophy of security] (in 2 Vols.), vol. 2: Bezpeka finansovykh instytutiv [Security of financial institutions]. Kyiv: UBS NBU. (in Ukrainian)

5. Brus S. I. (2011) Banky na fondovomu rynku Ukrainy: zmina investytsiinykh priorytetiv [Security of financial institutions]. Ekonomika i prohnozuvannia, no. 4, pp. 86-96. (in Ukrainian)

6. Reverchuk S. K. (ed.) (2002) Vlada. Banky. Biznes: politekonomiia vzaiemodii i rozvytku [Power. Banks. Business: political economy of interaction and development]. Kyiv: Atika. (in Ukrainian)

7. Vovk V. R. (2015) Vzaiemozviazok fondovoho rynku ta ekonomichnoho zrostannia [The relationship between the stock market and economic growth]. Visnyk Lvivskoho universytetu. Ser. Ekonomichna, no. 52, pp. 239-244. (in Ukrainian)

8. Vovk V. R. (2013) Osoblyvosti povedinky investora na fondovomu rynku. [Features of investor behavior in the stock market]. Visnyk Lvivskoho universytetu. Ser. Ekonomichna, no. 50, pp. 36-41. (in Ukrainian)

9. Bohdan T. P. (ed.) (2017) Vplyv hlobalnykh finansiv na valiutno-finansovu systemu [The impact of global finance on the monetary and financial system]. Kyiv: NAN Ukrainy, DU «In-t ekon. ta prohnozuv. NAN Ukrainy. (in Ukrainian)

10. Hrebeniuk N. O. (2016) Finansova bezpeka bankiv: systema rozpiznannia zahroz ta usunennia ryzykiv [Financial security of banks: a system for recognizing threats and eliminating risks]. Visnyk Kharkivskoho natsionalnoho universytetu imeni V. N. Karazina. Ser.: Ekonomichna, iss 91, pp. 53-64. (in Ukrainian)

11. National Bank of Ukraine (2019) Hroshovo-kredytna ta finansova statystyka NBU [Monetary and financial statistics of the NBU]. Retrieved from: https://bank.gov.ua/news/all/groshovo-kreditna-ta-finansova-statistika-cherven2019-roku (accessed 10 December 2020). (in Ukrainian)

12. Veklych O. O., Kobzar O. M., Kolmakova V. M., Patoka I. M. (2019) Ekosystemni zasady otsiniuvannia zbytkiv vid zabrudnennia navkolyshnoho pryrodnoho seredovyshcha [Ecosystems ambush the assessment of landmarks from the environment of the natural environment]. Kyiv: DU IEPSR NAN Ukrainy. (in Ukrainian) 
13. Cabinet of Ministers of Ukraine (2020) Zasady stratehichnoho reformuvannia derzhavnoho bankivskoho sektoru (stratehichni pryntsypy) [Ambush of the strategic reform of the sovereign banking sector (strategic principle)]. Retrieved from: https://mof.gov.ua/storage/files/SOB\%20Strategy.pdf(accessed 10 December 2020). (in Ukrainian)

14. National Bank of Ukraine. Zvit pro finansovu stabilnist [Financial Stability Report]. Retrieved from: https://bank.gov.ua/doccatalog/document?id=50604896 (accessed 10 December 2020). (in Ukrainian)

15. Koval Ya. S. (2019) Vdoskonalennia informatsiino-analitychnoi systemy ekonomichnoi bezpeky bankiv na derzhavnomu rivni [Improvement of the information and analytical system of economic security of banks on the state level]. Science Notes of "KROK" University, iss. 2(54), pp. 212-221. (in Ukrainian)

16. Kornyliuk R.(2017) Novyi indeks Bank_FinScore dlia YouControl [New Bank_FinScore index for YouControl]. Retrieved from: http://bankografo.com/ noviy-indeks-bank_finscore-youcontrol.html (accessed 10 December 2020). (in Ukrainian)

17. Lesyk V. O. (2015) Analiz problem rozvytku systemy monitorynhu finansovoi stabilnosti vitchyznianoho bankivskoho sektoru ekonomiky [Analysis of the problems of development of the system of monitoring the financial stability of the domestic banking sector of the economy]. Bankivska sprava, no. 3(134), pp. 69-77. (in Ukrainian)

18. Mihus I. P. Osoblyvosti zdiisnennia IRO na zarubizhnykh fondovykh birzhakh [Features of IPO implementation on foreign stock exchanges]. Science Notes of "KROK" University, iss. 2(54), pp. 184-190. (in Ukrainian)

19. Ofitsiinyi sait Derzhavnoi sluzhby statystyky Ukrainy [Official site of the State Statistics Service of Ukraine]. Retrieved from:www.ukrstat.gov.ua (accessed 10 December 2020). (in Ukrainian)

20. Ofitsiinyi sait Derzhavnoi sluzhby finansovoho monitorynhu Ukrainy [Official site of the State Financial Monitoring Service of Ukraine]. Retrieved from: http:// www.sdfm.gov.ua (accessed 10 December 2020). (in Ukrainian)

21. Ofitsiinyi sait Natsionalnoi komisii $\mathrm{z}$ tsinnykh paperiv ta fondovoho rynku [Official site of the National Commission on Securities and Stock Market]. Retrieved from: https://www.nssmc.gov.ua (accessed 10 December 2020). (in Ukrainian)

22. Ofitsiinyi sait PAT «Alfa-Bank» [Official site of PJSC "Alfa-Bank"]. Retrieved from: www.alfabank.com.ua (accessed 10 December 2020). (in Ukrainian)

23. Ofitsiinyi sait PAT «Universalbank» [Official site of PJSC "Universalbank"]. Retrieved from: www.universalbank.com.ua (accessed 10 December 2020). (in Ukrainian)

24. Ofitsiinyi sait PAT KB «Pryvatbank» [Official site of PJSC CB "Privatbank"]. Retrieved from: www.privatbank.ua (accessed 10 December 2020). (in Ukrainian)

25. Perekhrest L. M., Perekhrest Yu. A., Yakovleva A. A. (2012) Uperedzhennia finansovoi nestabilnosti bankiv yak napriam zmitsnennia bankivskoho sektoru ekonomiky [Prevention of financial instability of banks as a direction of 
strengthening the banking sector of the economy]. Zbirnyk naukovykh prats Natsionalnoho universytetu derzhavnoi podatkovoi sluzhby Ukrainy, no. 1, pp. 330-336. (in Ukrainian)

26. National Bank of Ukraine. Pokaznyky bankivskoi systemy [Indicators of the banking system]. Retrieved from: https://bank.gov.ua/control/uk/publish/ article?art_id $=34661442$ \&cat_id $=34798593$ (accessed 10 December 2020). (in Ukrainian)

27. FAO (2020) Polozhenie s prodovol'stviem v mire [World food situation]. Retrieved from: http://www.fao.org/worldfoodsituation/foodpricesindex/ru (accessed 10 December 2020). (in Russian)

28. Pryimak P. V. (2013) Monitorynh bankivskoi systemy yak pidkhid do upravlinnia yii rozvytkom [Monitoring of the banking system as an approach to managing its development]. Naukovyi visnyk NLTU Ukrainy, iss. 23.14, pp. 235-241. (in Ukrainian)

29. Verkhovna Rada of Ukraine (2000) Pro banky $i$ bankivsku diialnist [About banks and banking] (Act no. 2121-III, December 7). Retrieved from: https://zakon.rada.gov.ua/laws/show/2121-14 (accessed 10 December 2020).

30. Stepaniuk N. A. (2016) Analiz prychyn kryzovoi dynamiky ekonomiky Ukrainy [Analysis of the causes of the crisis dynamics of Ukraine's economy]. Hlobalni ta natsionalni problemy ekonomiky, iss. 10, pp. 227-230. (in Ukrainian)

31. AUB Expert Group Information and Analytical Center (2010) Uroky bankivsjkoji kryzy 2008-2009 rokiv i shljakhy strateghichnoji transformaciji bankivsjkoji ghaluzi Ukrajiny seredovyshha [Lessons from the banking crisis of 2008-2009 and ways of strategic transformation of the banking industry of Ukraine]. Retrieved from: http://www.aub.org.ua (in Ukrainian)

32. Cabinet of Ministers of Ukraine (2020) Uriad zatverdyv z doopratsiuvanniam Prohramu stymuliuvannia ekonomiky dlia podolannia naslidkiv epidemii COVID-19 [The Government approved with revision the Program of stimulation of economy for overcoming of consequences of epidemic COVID-19]. Retrieved from: https://www.kmu.gov.ua/news/uryad-zatverdiv-z-doopracyuvannyam-programustimulyuvannya-ekonomiki-dlya-podolannya-naslidkiv-epidemiyi-covid-19 (accessed 10 December 2020). (in Ukrainian)

33. Shapoval M. S. (2017) Dominanty rozvytku fondovoho rynku v Ukraini [Dominants of stock market development in Ukraine]. Naukovyi visnyk Uzhhorodskoho natsionalnoho universytetu. Ser: Mizhnarodni ekonomichni vidnosyny ta svitove hospodarstvo, iss. 12(2), pp. 157-160. (in Ukrainian)

34. Shpylova Yu. B. (2019) Stalyi rozvytok silskykh terytorii Ukrainy v umovakh detsentralizatsii vlady [Sustainable development of rural areas of Ukraine in the conditions of decentralization of power]. Kyiv: ProfKnyha. (in Ukrainian)

35. Yaremenko S. M. (2010) Zabezpechennia ekonomichnoi bezpeky diialnosti bankiv [Ensuring economic security of banks] ( $\mathrm{PhD}$ Thesis). Kyiv. (in Ukrainian)

36. Laptiev S., Sidak V., Mihus I., Koval Y. (2019) Actions to improve crisis management of economic security of banking institutions at the national level. Management mechanisms and development strategies of economic entities in 
conditions of institutional transformations of the global environment (in 2 Vols.). Riga: Landmark SIA, vol. 2, pp. 216-224.

37. BlackRock. BlackRock and iShares global site directory. Retrieved from: https://www.blackrock.com/corporate/global-directory (accessed 10 December 2020).

38. Bloomberg. Bloomberg Professional. Retrieved from: https://www.bloomberg. $\mathrm{com} / \mathrm{professional} / \mathrm{solution} / \mathrm{bloomberg}$-terminal (accessed 10 December 2020).

39. Cheung F. M., Hong Y. (2020) Green Finance, Sustainable Development and the Belt and Road Initiative. Routledge. Retrieved from: https://books.google.com.ua/ books? $\mathrm{id}=$ wOAIEAAAQBAJ \& printsec $=$ frontcover $\& \mathrm{dq}=$ green + finance $\& \mathrm{hl}=\mathrm{ru} \& \mathrm{~s}$ $\mathrm{a}=\mathrm{X} \& \mathrm{ved}=2 \mathrm{ahUKEwisqe}-\mathrm{NqbztAhVKw4sKHTvVDfsQ6AEwAHoECAQQAg \# v}$ $=$ onepage $\& \mathrm{q}=$ green $\% 20$ finance $\& \mathrm{f}=$ false $($ accessed 10 December 2020$)$.

40. Federal Reserve Bank of St. Louis. Federal Reserve Economic Data. Retrieved from: https://research.stlouisfed.org/ (accessed 10 December 2020).

41. Sang-Bing T., Chung-Hua S., Hua S., Baozhuang N. (2019) Green Finance for Sustainable Global Growth. IGI Global. Retrieved from: https://books.google.com.ua/ books? $\mathrm{id}=\mathrm{KvGCDwAAQBAJ} \& \mathrm{pg}=\mathrm{PA} 63 \& \mathrm{dq}=$ green + finance $\& \mathrm{hl}=\mathrm{ru} \& \mathrm{sa}=\mathrm{X} \& \mathrm{ved}$ $=2$ ahUKEwisqe-NqbztAhVKw4sKHTvVDfsQ6AEwA3oECAIQAg\#v=onepage $\& \mathrm{q}=$ green $\% 20$ finance $\& \mathrm{f}=$ false (accessed 10 December 2020).

42. Hockett R. C. (2020) Financing the Green New Deal: A Plan of Action and Renewal. Springer Nature. Retrieved from: https://books. google.com.ua/books?id=Ibb1DwAAQBAJ\&printsec=frontcover\&d$\mathrm{q}=\mathrm{New}+\mathrm{Green}+$ Deal $\&$ hl $=$ ru\&sa $=\mathrm{X} \& \mathrm{ved}=2$ ahUKEwiqxcOMnrztAhXNlYsKHRC4Ag0Q6AEwAnoECAAQAg\#v=onepage \& $\mathrm{q}=\mathrm{New} \% 20 \mathrm{Green} \% 20$ Deal\& $\mathrm{f}=$ false (accessed 10 December 2020).

43. Koval Y. S. (2018) Stress-testing of complex risks in the banking system, as an instrument of state anti-crisis management. Public management: collection, no. 2, (12), pp. 138-148.

44. Merton R. C. (1993) Financial Innovation and Economic Performance. Journal of Financial Service Research, vol. 4.4, pp. 263-271. Retrieved from: http://onlinelibrary.wiley.com/doi/10.1111/j.1745-6622.1992.tb00214.x/abstract (accessed 10 December 2020).

45. United Nations (2015) Paris Agreement. Retrieved from: https://unfccc.int/ sites/default/files/english_paris_agreement.pdf (accessed 10 December 2020).

46. Rifkin J. (2019) The Green New Deal: Why the Fossil Fuel Civilization Will Collapse by 2028, and the Bold Economic Plan to Save Life on Earth. St. Martin's Publishing Group. Retrieved from: https://books.google.com.ua/books?id=KkCLD wAAQBAJ\&printsec $=$ frontcover $\& \mathrm{dq}=\mathrm{New}+\mathrm{Green}+$ Deal $\& \mathrm{hl}=\mathrm{ru} \& \mathrm{sa}=\mathrm{X} \& \mathrm{ved}=2 \mathrm{ah}$ UKEwjg---3nbztAhXwsYsKHbW4ACsQ6AEwAHoECAYQAg\#v=onepage\&q= New\%20Green\%20Deal\&f=false (accessed 10 December 2020).

47. European Central Bank (2005). Statistical Classification Of Financial Markets Instruments. Retrieved from: https://www.ecb.europa.eu/pub/pdf/other/ statisticalclassificationfmi200507en.pdf?05d940969ab122b2d9aa7b512e2d29fa (accessed 10 December 2020).

48. The Securities Industry and Financial Markets Association (SIFMA). Statistics and data pertaining to financial markets and the economy. US Bond 
Market Issuance and Outstanding. Retrieved from: http://www.sifma.org/research/ statistics.aspx (accessed 10 December 2020).

49. European Commission (2019) The European Green Deal sets out how to make Europe the first climate-neutral continent by 2050, boosting the economy, improving people's health and quality of life, caring for nature, and leaving no one behind. Retrieved from: https://ec.europa.eu/commission/presscorner/detail/ en/ip_19_6691 (accessed 10 December 2020).

$5 \overline{0}$. United Nations (2020) The Sustainable Development Goals Report 2020. Retrieved from: https://unstats.un.org/sdgs/report/2020/The-SustainableDevelopment-Goals-Report-2020.pdf (accessed 10 December 2020).

51. Tobin J. (1980) Stabilization policy ten years after. Brookings Papers on Economic Activity, Brookings Institution, no. 11(1), pp. 19-90.

52. United Nations (2015) Transforming our world: the 2030 Agenda for Sustainable Development. Retrieved from: https://sustainabledevelopment. un.org/content/documents/21252030\%20Agenda $\% 20$ for $\% 20$ Sustainable $\% 20$ Development\%20web.pdf (accessed 10 December 2020).

53. World Bank. World Bank Open Data. Retrieved from: https://data.worldbank.org (accessed 10 December 2020). 